\title{
Hydrobiological Aspects of Saturated, Methyl-Branched, and Cyclic Fatty Acids Derived from Aquatic Ecosystems: Origin, Distribution, and Biological Activity
}

\author{
Valery M. Dembitsky
}

Centre for Applied Research, Innovation and Entrepreneurship, Lethbridge College, 3000 College Drive South, Lethbridge, AB T1K 1L6, Canada; valery.dembitsky@lethbridgecollege.ca; Fax: +1-888-858-8517

\begin{abstract}
This review focuses on the hydrobiological aspects of saturated, methyl-branched, and cyclic fatty acids (FA) derived from aquatic ecosystems. This short review presents the distribution of about 60 FA in various living organisms inhabiting the aquatic environment as well as in marine and freshwater sediments. In addition, it is important to determine the biological activity of saturated, methyl-branched, and cyclic fatty acids. An interesting finding was that some cyclic FA show antiplatelet activity. The generalized and presented data are of interest to hydrobiologists, chemists, and pharmacologists.
\end{abstract}

Keywords: aquatic organisms; saturated; cyclic; fatty acids; biological activity

check for

updates

Citation: Dembitsky, V.M.

Hydrobiological Aspects of

Saturated, Methyl-Branched, and Cyclic Fatty Acids Derived from Aquatic Ecosystems: Origin, Distribution, and Biological Activity. Hydrobiology 2022, 1, 89-110. https://doi.org/10.3390/ hydrobiology 1010007

Academic Editor: Roberta Congestri

Received: 15 December 2021

Accepted: 25 January 2022

Published: 28 January 2022

Publisher's Note: MDPI stays neutral with regard to jurisdictional claims in published maps and institutional affiliations.

Copyright: (c) 2022 by the author. Licensee MDPI, Basel, Switzerland. This article is an open access article distributed under the terms and conditions of the Creative Commons Attribution (CC BY) license (https:// creativecommons.org/licenses/by/ $4.0 /)$.

\section{Introduction}

Fatty acids (FA) are important components of complex lipids such as mono-, di-, and triglycerides, glycolipids, phospholipids, and steryl esters [1-25]. In addition, FA are the building blocks of fat both in the bodies of animals and in food that living organisms eat [1-3,13-15]. Typically, FA are carboxylic acids with aliphatic chains of various lengths: short chain $(\mathrm{C} 1-\mathrm{C} 7)$, medium chain $(\mathrm{C} 8-12 \mathrm{C})$, long chain $(\mathrm{C} 13-\mathrm{C} 22)$, and very long chain (C24-C36). The most common FA chain length range is between $\mathrm{C} 14$ and C20 [1,4-10,16-25]. During digestion, the body breaks down dietary fats into FA, which then enter the bloodstream. FA molecules combine in groups of three FA to form a molecule called triglyceride [15]. Complex lipids are the basis of the biological membranes of marine organisms, algae, plants, fungi, animals, and microorganisms [1-3,5-12,17-22]. The biochemistry and chemistry of FA are well studied, made up of aliphatic chains that contain a carboxyl group $(-\mathrm{COOH})[1,2]$. The most naturally occurring FA have an unbranched chain with an even number of carbon atoms, from 4 to 36; however, odd FA are also widely present, especially in microorganisms [1,3]. In either of these forms, fatty acids are important dietary fuel sources for animals and important structural components for cells. FA can be both saturated and non-stressed. The full names of lipids and fatty acids can be found in a published article titled: 'The nomenclature of lipids' [2].

\section{Acyclic Aliphatic Fatty (Carboxylic) Acids}

The saturated FA shown in Figure 1 are the most abundant in a variety of natural sources. The first on this list is caprylic acid (1), which was first found in goat milk along with caproic acid (C6) and capric acid (2), and these acids together make up over $15 \%$ of the FA in goat milk fat $[26,27]$.

The n-saturated (1-9, see Figure 1), iso- (16-22, see Figure 2) and anteiso- (29-35, see Figure 2), branched-chain (48-53, see Figure 3) FA series occur in many bacteria as the major acyl constituents of membrane lipids. In addition, $\omega$-cyclohexyl (58) and $\omega$-cycloheptyl (59) FA are present in several bacterial species $[28,29]$. Cyclopropane FA, containing three carbon rings located at different sites of the FA chain (55-57, see Figure 3), occur widely 
in several microorganisms as major lipid components and in certain eukaryotes including protozoa, fungi, and plants [30-33].

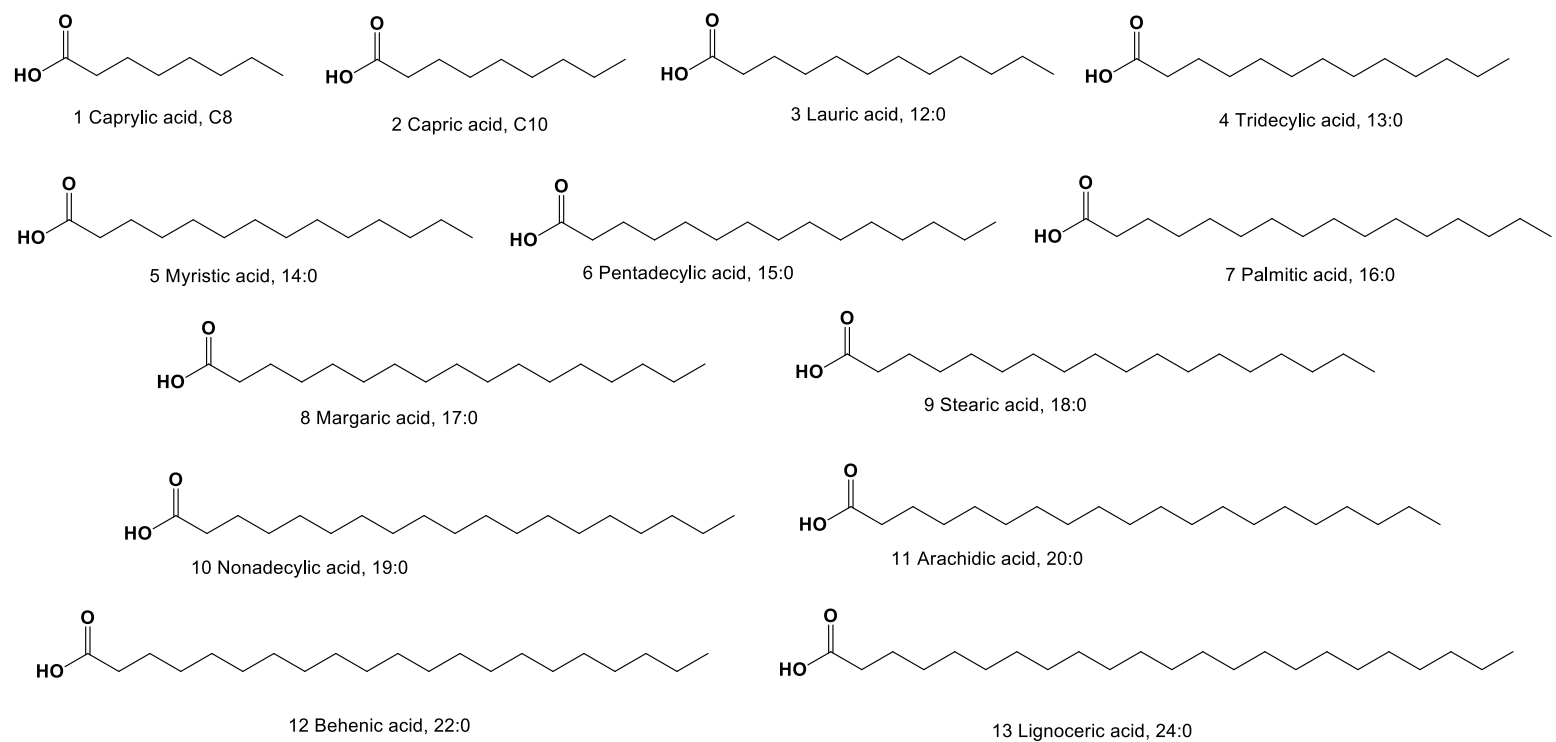

Figure 1. Saturated FA derived from different sources.
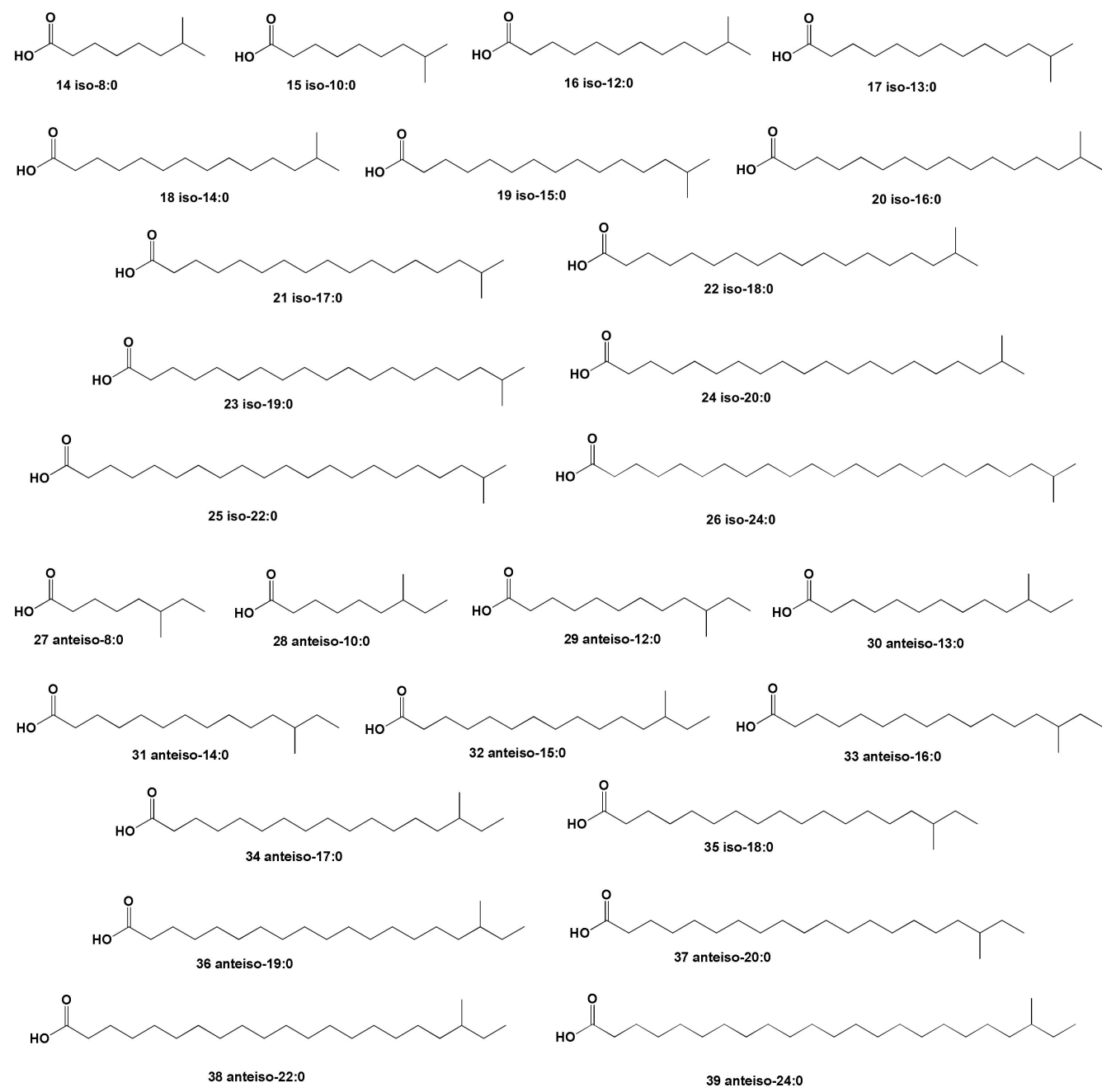

Figure 2. An iso- and anteiso-FA derived from different sources. 

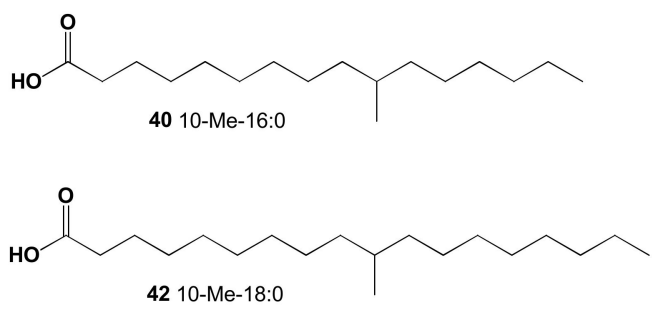

42 10-Me-18:0

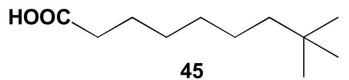

HOOC

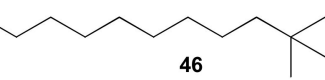

HOOC

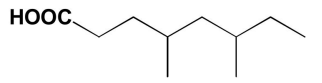

48 4,6-dimethyloctanoic acid

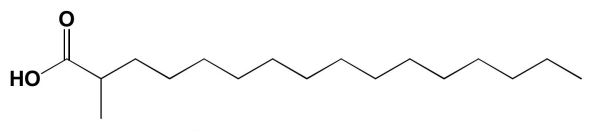

41 2-Me-Palmitic acid, 16:0<smiles>CCCC(CC)CC(=O)O</smiles>

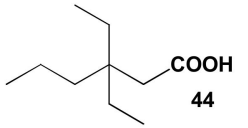

HOOC

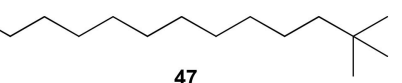

HOOC<smiles>CC(C)CCCC(C)CCCC(C)CCCC(C)C</smiles>

50 Phytanic acid<smiles>CC(C)CCCC(C)CCCC(C)CCCC(C)CC(=O)O</smiles>

51 Pristanic acid

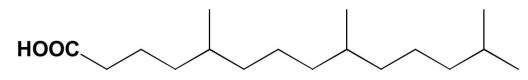

53 5,9,13-TM-14:0

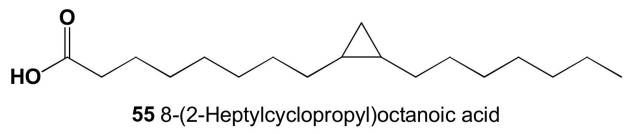

車

57 6-(2-decylcyclopropyl)hexanoic acid<smiles>CC(CCCC(=O)O)CCCC(C)CCC(=O)C(C)C</smiles>

HOOC

52

HOOC<smiles>CCCCCC(C)CCCC(C)C</smiles>

54 2,6,10-TM-11:0

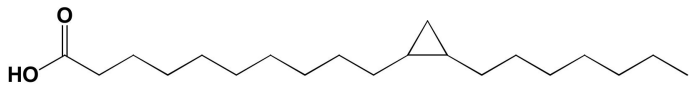

56 10-(2-Heptylcyclopropyl)decanoic acid

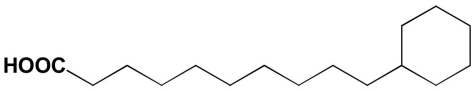

$58 \omega$-cyclo-17,11-cyclohexyl undecanoic acid

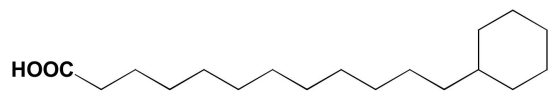

59 œ-cyclo-19,13-cyclohexyl tridecanoic acid

Figure 3. Cyclic and miscellaneous FA derived from different sources.

Bacillus is a genus of Gram-positive rod-shaped bacteria whose FA composition is the most well-studied. Thus, FA produced by 22 strains of 10 species of the genus Bacillus (see Figure 4 were studied. All 10 species, B. alvei, B. brevis, B. cereus, B. circans, B. licheniformis, B. macerans, B. megaterium, B. polymyxa, B. pumilus, and B. subtilis, produced eight unusual fatty acids, six branched (anteiso-15:0, anteiso-17:0, iso-14:0, iso-15:0, iso-16:0, and iso-17:0) and two n-14:0 and n-16:0. In all cases, the six branched chain FA accounted for more than $60 \%$ of the total FA. In addition to the eight FA, B. cereus produced four additional FA, three branched (anteiso-13:0, iso-12:0, and iso-13:0) and one monoene-n-C16 [29,34,35]. 

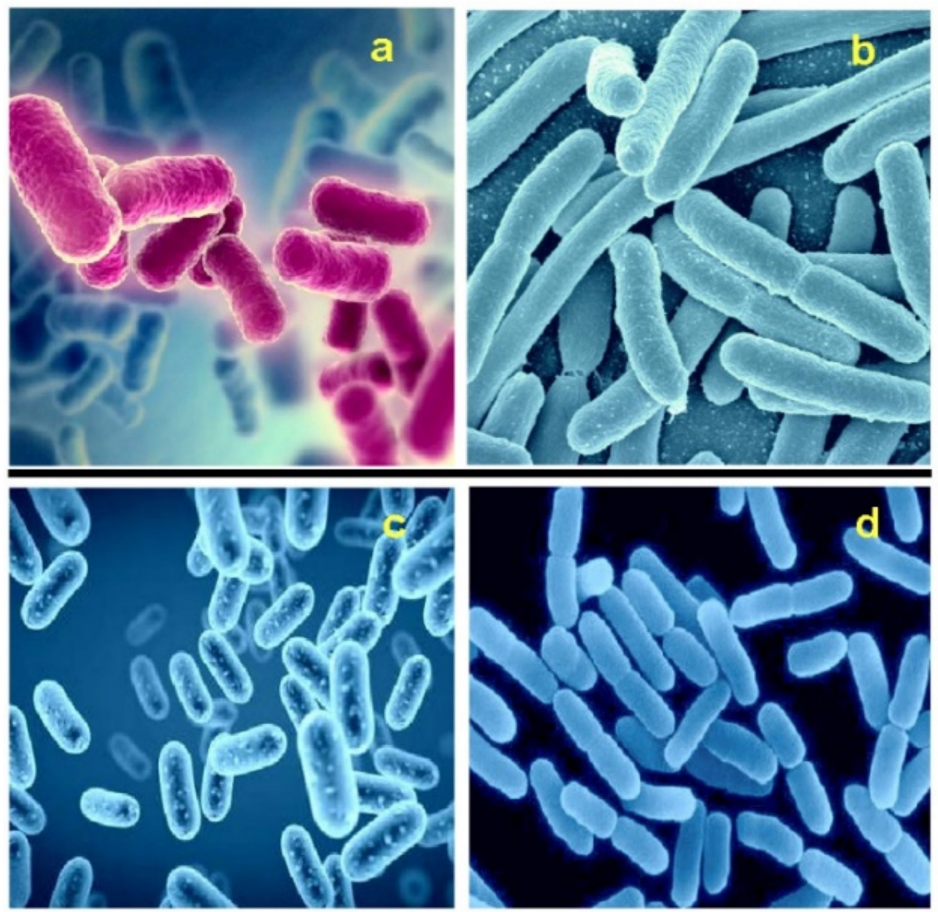

Figure 4. Gram-positive, rod-shaped bacteria belonging to the genus Bacillus: (a) B. subtilis, (b) B. cereus, (c) B. megaterium, and (d) B. polymyxa, widely found in water and soil, are producers of saturated, iso-, anteiso-, and branched-chain and cyclic FA. All photos are taken from sites where permission is granted for non-commercial use.

n-Straight chain, iso-, and anteiso-acids from different sedimentary environments of the North Atlantic have also been studied. Acids cover the range from C7 to C21. Normal and iso-acids occur at every number; anteiso-acids occur only at odd carbon numbers within the same range. It is suggested that the iso- and anteiso-acids may provide markers for the bacterial contribution, and the isoprenoid acid markers for the contribution of animal and plant lipids to the organic matter of recent sediments [36]. Sediment samples were taken from a mangrove swamp in the Low Islands, North Queensland, in the Great Barrier Reef, Australia. The FA composition consisted of n-saturated (1-13, structures in Figure 1), iso(15-22, structures in Figure 2) and anteiso- (32-34, structures in Figure 2), branched (49), and cyclopropane containing (55 and 56, Figure 3) FA [37]. The authors believe that FA found in marine sediments are of bacterial origin.

The composition of FA extracted from the cyanobacteria Synechocystis sp. PCC 6803, Anabaena variabilis ATCC 29413 (see Figure 5), Synechococcus sp. PCC 7002, and Cyanothece sp. ATCC 51142 strains were reported, and the thylakoid membrane contained: C8:0 (caprylic), C10:0 (capric), C12:0 (lauric), C16:0 (palmitic), and C18:0 (stearic) acids [38]. The microalgae Arthrospira platensis (see Figures 5 and 6), A. maxima and A. pacifica contained 3.7 to 4 percent caprylic acid, while this FA ranged between 0.26 and 4 percent in Chlorella vulgaris and C. pyrenoidosa [39]. 

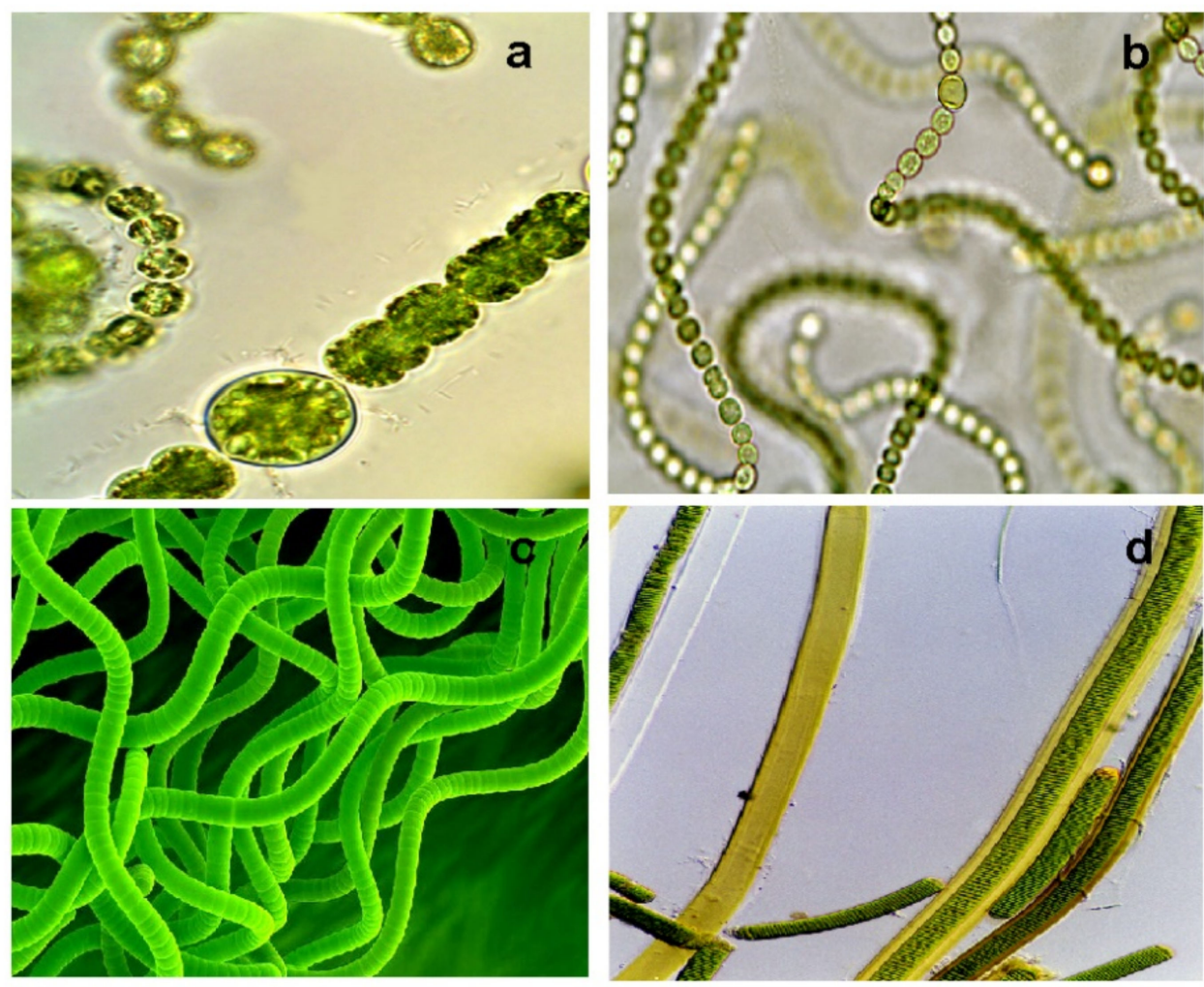

Figure 5. Cyanobacteria: (a) Anabaena planctonica; (b) Nostoc commune; (c) Arthrospira platensis; (d) Lyngbya sp. living in aquatic environments and producing saturated and branched FA.

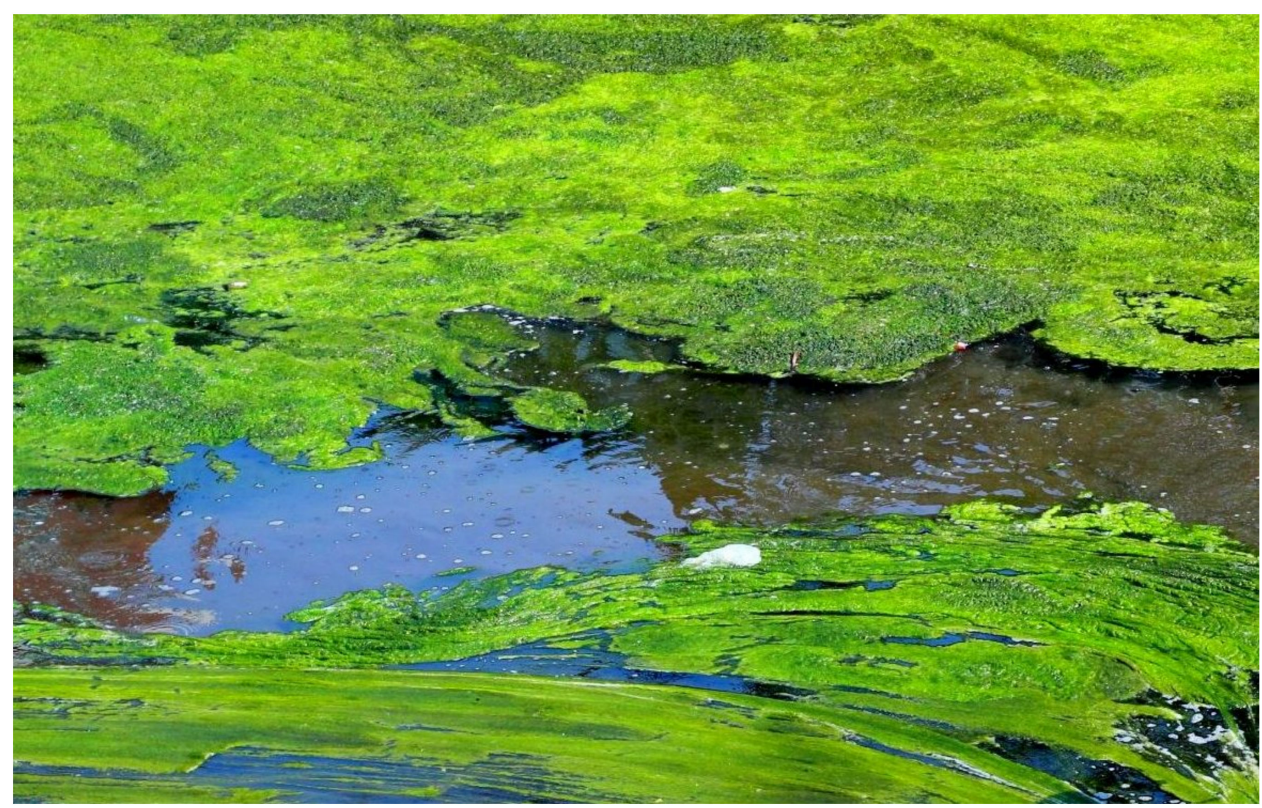

Figure 6. Arthrospira is a free-floating filamentous cyanobacterium that naturally occurs in tropical and subtropical lakes or stagnant rivers and swamps. Several types of Arthrospira are cultivated in many countries around the world and are used as a feed additive in aquaculture, aquariums, and poultry farming. All Arthrospira species contain saturated and methyl-branched FA.

A more detailed analysis of FA using gas chromatography-mass spectrometry (GCMS) of various cyanobacteria species showed that these organisms contain caprylic, capric, and lauric acids in low proportions from 0.15 to 0.5 percent. n-Saturated FA (1-9), iso-FA 
(14-18), and $\omega$-cyclic FA (58) in six freshwater wild cyanobacteria (Chroococcus minutus, Lyngbya ceylanica (see Figure 5), Merismopedia glauca, Nodularia sphaerocarpa, Nostoc linckia, and Synechococcus aeruginosus) collected from different lakes and springs of Israel were found [40]. In addition, these FA were found in three species of wild terrestrial strains of the genus Chroococcidiopsis (see Figure 7): C. supralittoralis, C. umbratilis, and C. versatilis, which were collected from Lake Kinneret, Dead Sea, and Ein Kerem (Jerusalem) [41].

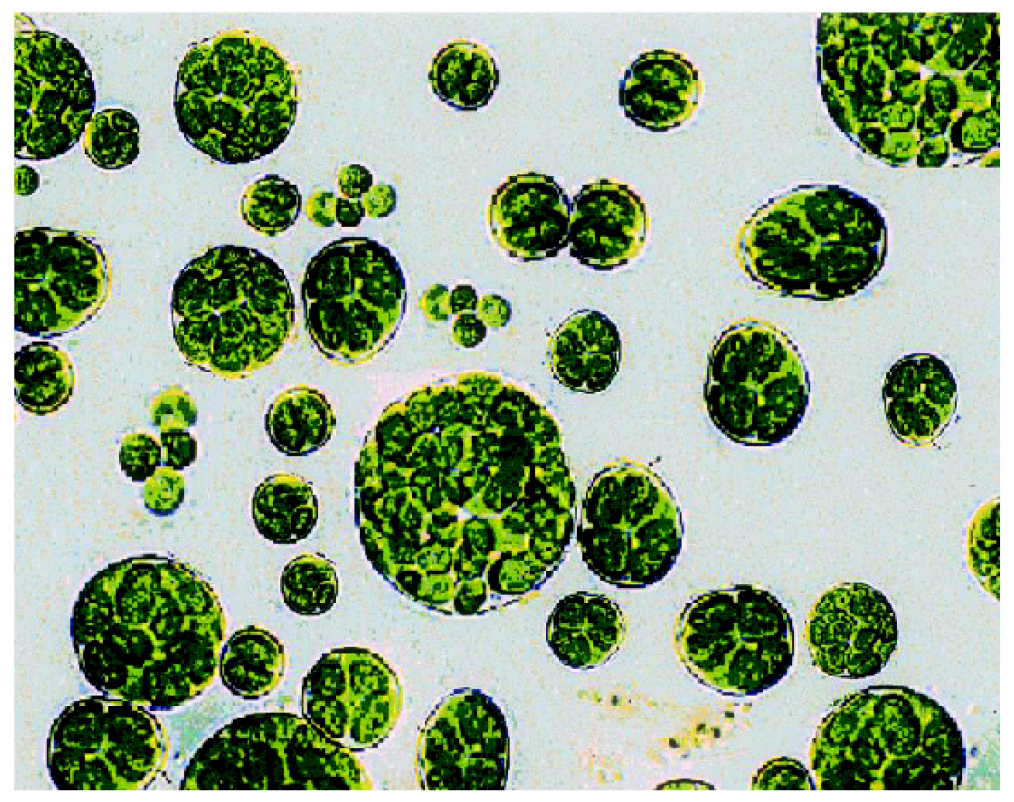

Figure 7. Microphotograph of the strain Chroococcidiopsis versatilis, originally isolated from the sublittoral hypersaline solar pond at the Dead Sea.

Low molecular, hydroxy, dioic, saturated (1-11, 14-21, 27-34), and unsaturated FA were identified in about 50 cyanobacterial species belonging to the genus Nostoc (see Figure 5) and in different habitats: freshwater, terrestrial as well as symbionts. There were large variations in individual fatty acid contents according to species and location of the genus Nostoc. Statistical analysis of the variability of fatty acids belonging to the genus Nostoc was reported [42]. The FA composition of many species of cyanobacteria, which are summarized in some reviews, show that various types of cyanobacteria contain saturated acids (1-10), iso-FA (14-23), and anteiso-FA (27-36) [43-49]. Moreover, carboxylic acids (1-40) have been found in the lipopeptides of cyanobacteria [50-53].

It is known that monounsaturated and polyunsaturated FA possess many nutritional properties, and their main sources are marine red, brown, and green algae [48,54-59]. Saturated FA have always been of less interest since they were assumed to have no practical value for human and animal health [60-62].

The genus of green seaweed Codium (algae of genus Codium are shown in Figure 8) includes about 50 species in different parts of the world's oceans, and the FA composition has only been studied in 12 species. For all studied species, Codium decorticatum, C. dichotomum, C. duthiae, C. dwarkense, C. elongatum, C. flabellatum, C. flabellatum, C. galeatum, C. harveyi, C. intractum, C. iyengarii, C. muelleri, C. pomoides, C. taylorii, and C. fragile were characterized by the presence of saturated FA (2-13) as well as some iso- (18-21) and anteiso-FA (30-35) [63-65].

Caprylic acid (1) and some other saturated FA such as lauric (3), tridecylic (4), myristic (5), pentadecylic (6), palmitic (7), margaric (8), stearic (9), and nonadecyclic (10) acids were found in acetone extracts of the brown algae Padina pavonica and Hormophysa triquetra and these acids showed antimicrobial activity against Gram-negative bacteria E. coli and Gram-positive bacteria S. aureus [66]. 
When studying Chlorophyceae (Ulva rotundata and Enteromorpha intestinalis), Pheophyceae (Laminaria saccharina, L. digitata, Fucus vesiculosus, Undaria pinnatifida, and Halidrys siliquosa), and Rhodophyceae (Porphyra umbilata and Gracilaria verrucosa), the authors showed that 14:0, 16:0, and 18:0 dominated among the saturated FA, while 12:0, 13:0, 15:0, 17:0, and 20:0 were found among minor FA [67]. Samples of marine brown algae are shown in Figure 9, and red algae are shown in Figure 10.

FA from more than twenty aquatic and terrestrial moss species were studied and among the saturated acids, n-saturated (2-13), iso- (16-21), anteiso- (30-36), and branched (49-51) have been found [68-70].
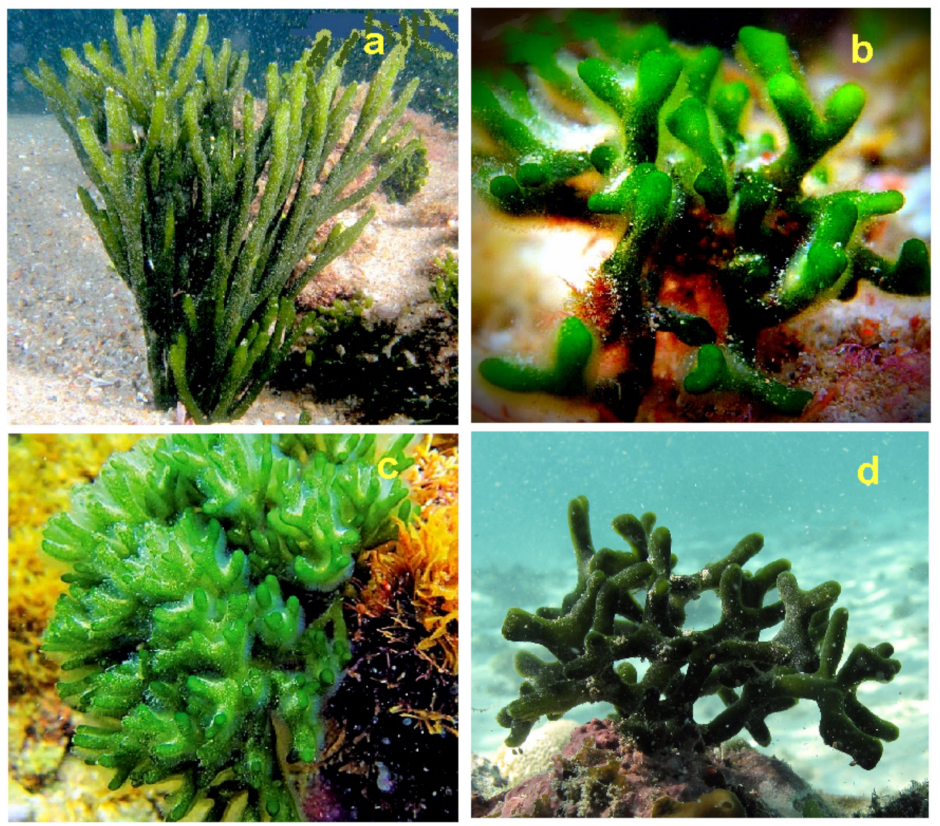

Figure 8. Green algae belonging to the genus Codium: (a) C. capitatum; (b) C. dwarkense; (c) C. taylorii; and (d) Codium sp. live in different zones of the world's oceans and contain different types of saturated and methyl-branched FA.

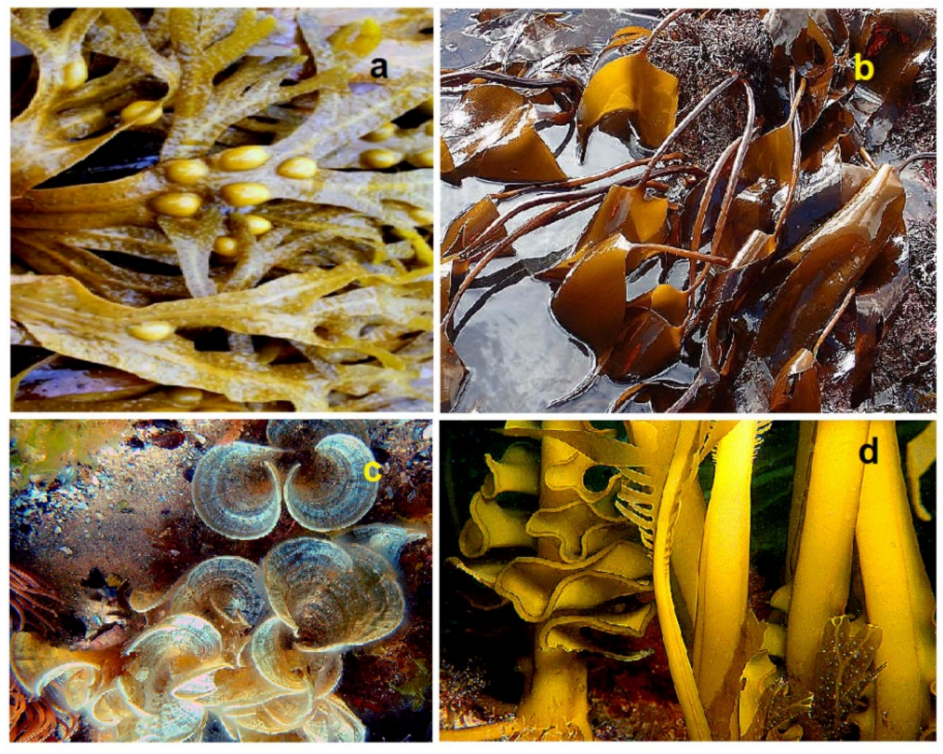

Figure 9. Marine brown algae: (a) Fucus vesiculosus; (b) Laminaria digitata; (c) Padina pavonica; and (d) Undaria pinnatifida contain a wide range of saturated and methyl-branched FA. 

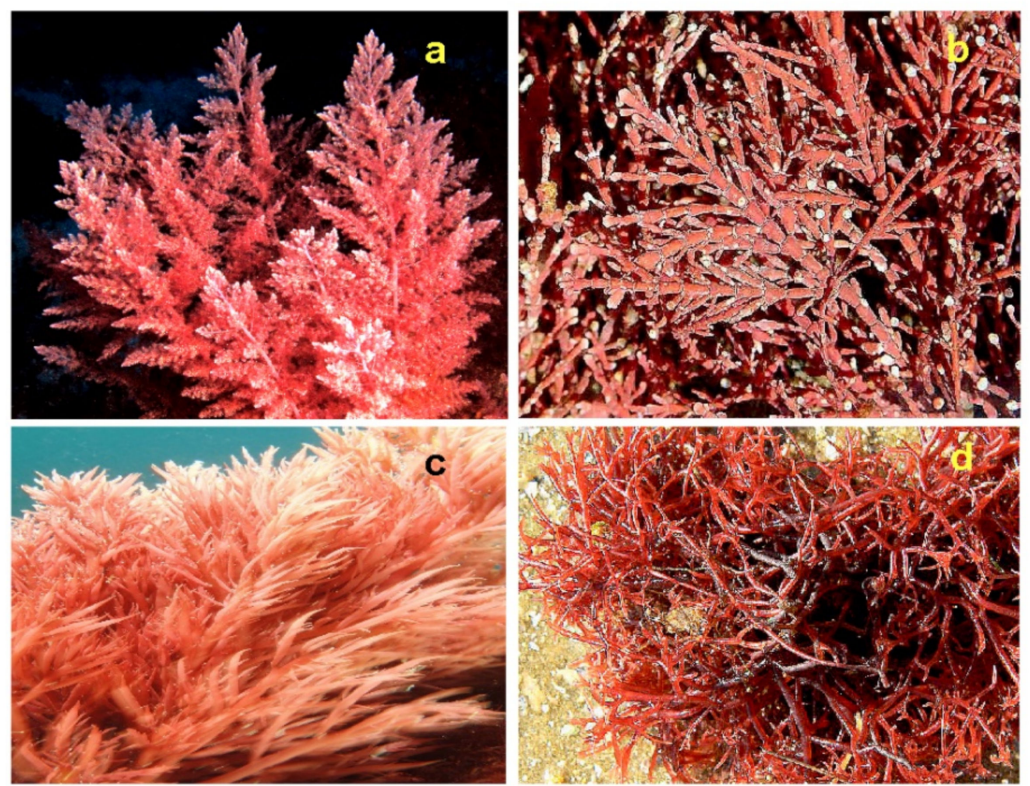

Figure 10. Marine red algae: (a) Asparagopsis taxiformis; (b) Corallina officinalis; (c) Porphyra umbilicalis; and (d) Gracilaria verrucosa contain an interesting spectrum of saturated and methyl-branched FA.

Freshwater and marine invertebrates contain a wide variety of saturated FA [71-75]. For instance, freshwater sponges Lubomirskia baikalensis, Baikalospongia bacillifera, and $B$. intermedia from Lake Baikal contain n-saturated (2-13), iso- (16-26), anteiso- (29-39), and other acids (49-51) [76-78]. Very-long-chain and multibranched polyunsaturated and saturated FA of three freshwater sponges, Ephydatia syriaca, Nudospongilla sp. and Cortispongilla barroisi belonging to the family Spongillidae (class Demospongia) were studied and the saturated FA were found to be like the acids found in Baikal freshwater sponges [79-81]. Examples of freshwater sponges from Lake Baikal are shown in Figure 11, whereas further examples of freshwater sponges are shown in Figure 12.

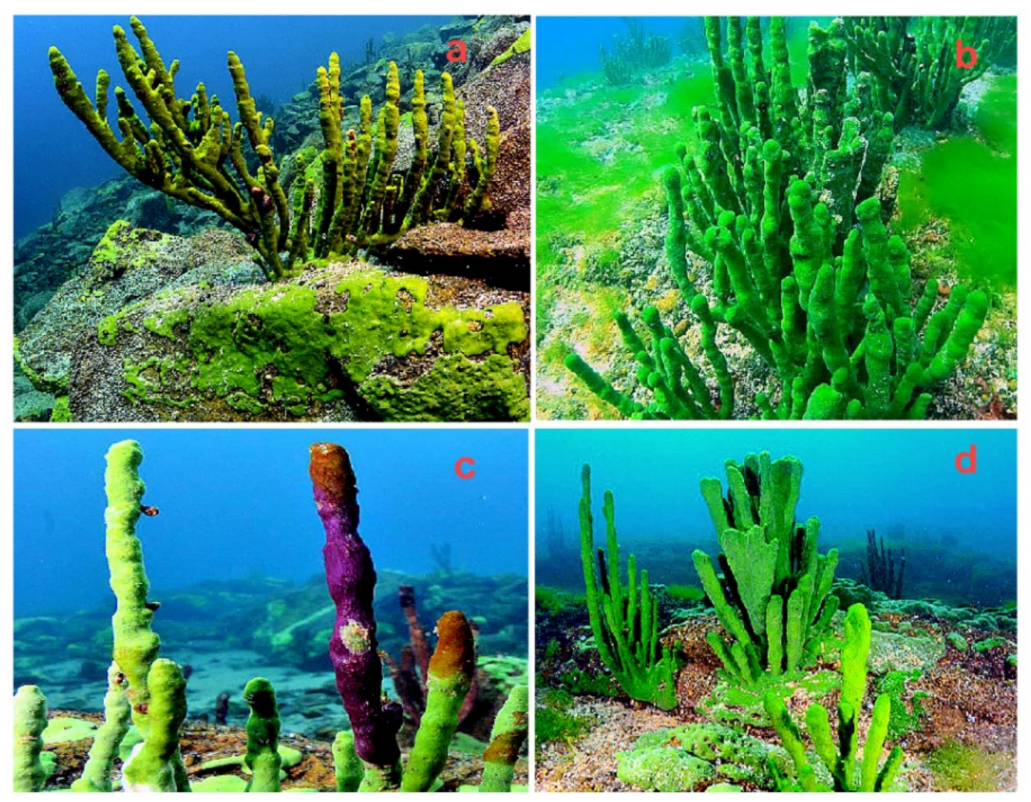

Figure 11. Endemic freshwater sponges of Lake Baikal, living at depths from 100 to $1500 \mathrm{~m}$ : (a) Lubomirskia sp.; (b) Lubomirskia baikalensis; (c) Lubomirskia sp. and (d) Lubomirskia baikalensis. All these sponge species contain saturated and methyl-branched FA. 

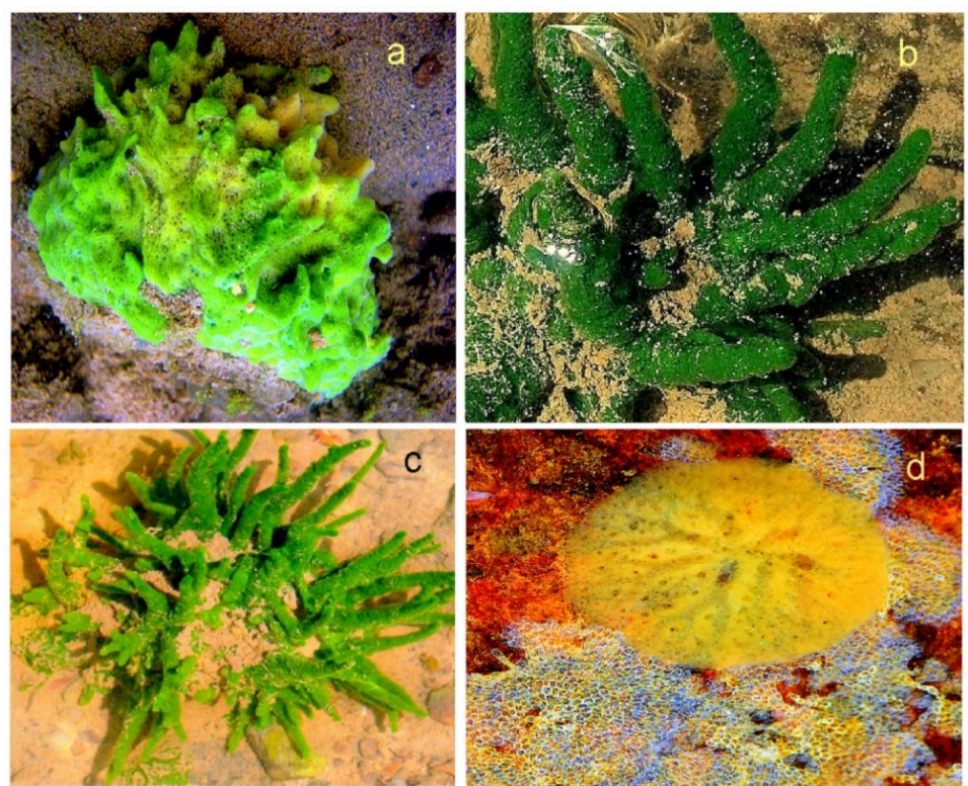

Figure 12. Samples of freshwater sponges: (a) Ephydatia fluviatilis; (b) Spongilla sp.; (c) Spongilla lacustris; (d) Ephydatia sp. living in rivers and lakes synthesize a different FA including saturated, branched, and unsaturated.

Marine sponges are of particular interest to scientists due to their ability to synthesize many different chemically interesting and unusual molecules. FA of marine sponges are no exception and are of great practical importance both for chemists, pharmacologists, and physicians due to their high biological activity. Almost all the saturated acids (1-57) that are presented in this article were found in various marine sponges, of which more than 600 species have been studied [82-90]. Several specimens of marine sponges found in various regions of the oceans are shown in Figure 13.

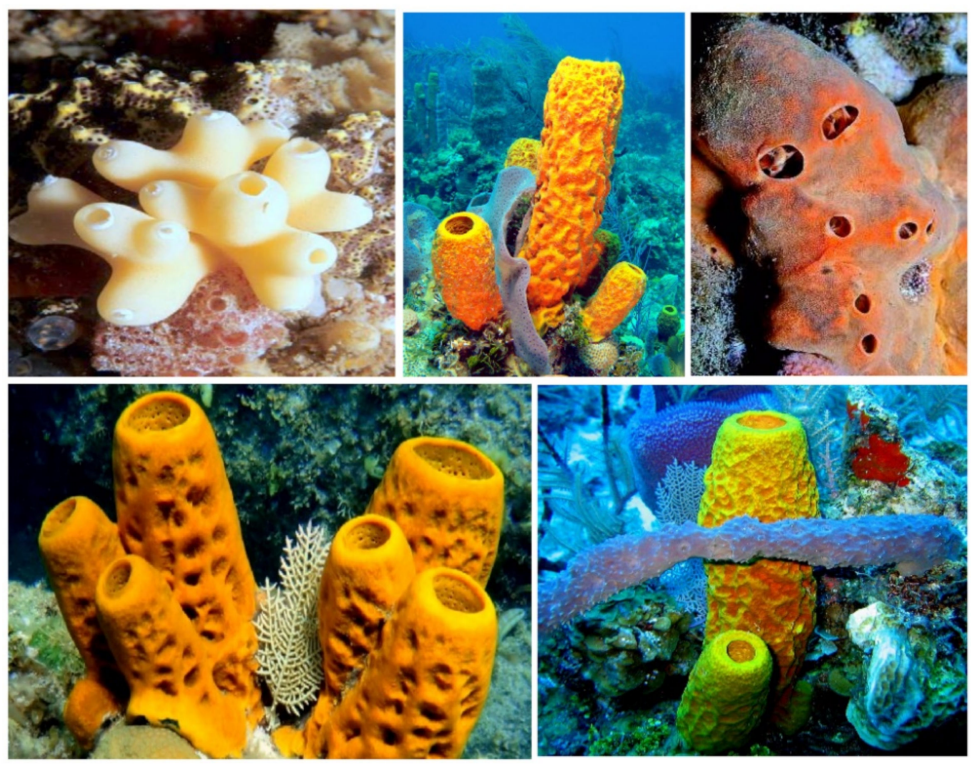

Figure 13. Photos of samples of marine sponges. These invertebrates synthesize a wide variety of biologically active and unusual metabolites including saturated, iso-, anteiso-, and branched-chain FA.

Molluscs are one of the most diverse and widespread groups of invertebrates in freshwater and marine habitats. Unfortunately, due to human activities, freshwater and 
marine taxa of molluscs are among the most endangered invertebrates on Earth, and many species are on the verge of extinction [91-96].

The study of the composition of saturated FA of mollusks living in sea, fresh, or brackish waters has shown no fundamental difference in the qualitative composition of acids, but there are significant differences in the quantitative composition [97-106]. The main fatty acids that have been found in marine and freshwater molluscs are saturated (4-11), iso(17-23), anteiso- (31-35), and other (49-51, 53). Examples of freshwater molluscs are shown in Figure 14, whereas some species of nudibranch molluscs are shown in Figure 15.

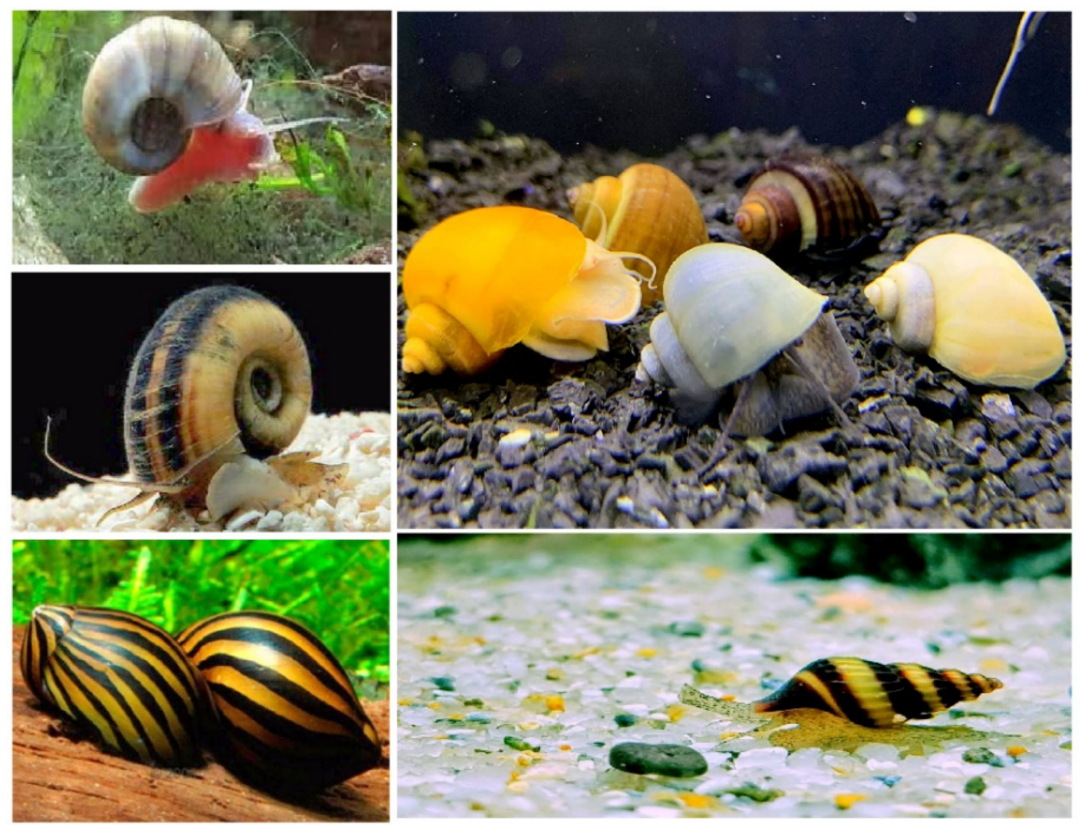

Figure 14. Samples of freshwater snails that have been tested for FA content. Experiments have shown that the lipids of these mollusks contain saturated, methyl-branched, and unsaturated FA.

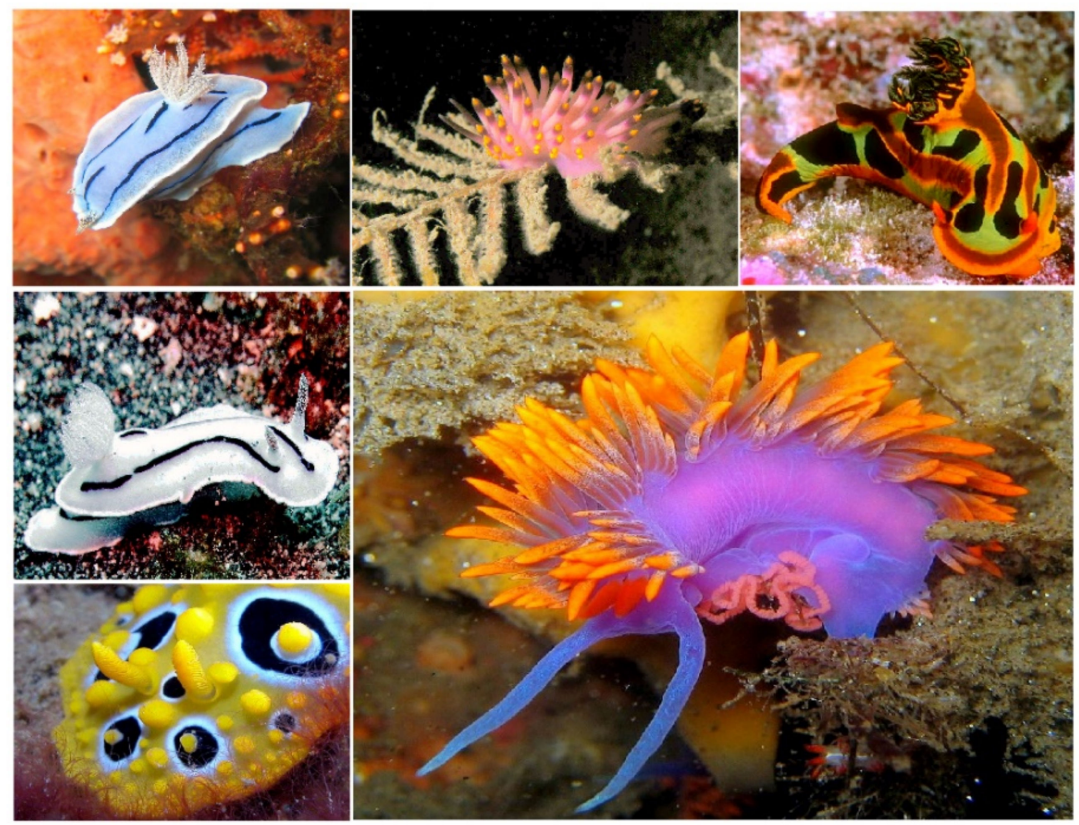

Figure 15. Examples of nudibranchs, a group of soft-bodied marine gastropods that shed their shells after the larval stage. Nudibranchs are often called sea slugs and contain a range of saturated, methyl-branched, and unsaturated FA. 


\section{Comparison of Biological Activities of Natural Saturated Fatty Acids}

It is known that the chemical structure of both natural molecules predetermines biological activity, which makes it possible to analyze the structure-activity relationships (SAR). This concept was first proposed by Brown and Fraser more than 150 years ago in 1868 [107]. According to other sources [108], SAR was used from the field of toxicology, according to which Cros, in 1863, determined the relationship between the toxicity of primary aliphatic alcohols and their solubility in water. More than 30 years later, Richet in 1893 [109], Meyer in 1899 [110], and Overton in 1901 [111] separately found a linear correlation between lipophilicity and biological effects. By 1935, Hammett [112,113] presented a method for accounting the effect of substituents on reaction mechanisms using an equation that considered two parameters: the substituent constant and the reaction constant. Complementing Hammett's model, Taft in 1956 proposed an approach to separate the polar, steric, and resonance effects of substituents in aliphatic compounds [114]. Combining all previous developments, Hansch and Fujita laid out the mechanistic basis for the development of the QSAR method [115], and the linear Hansch equation and Hammett's electronic constants are detailed in the book by Hansch and Leo published in 1995 [116].

Some popular computer programs can, with some degree of reliability, estimate the pharmacological activity of organic molecules isolated from natural sources or synthesized compounds [117-119]. It is known that classical SAR methods are based on the analysis of (quantitative) structure-activity relationships for one or more biological activities by using organic compounds belonging to the same chemical series as the training set [120].

The computer program PASS (prediction of activity spectra for substances), which has been continuously updated and improved for the past thirty years [121], is based on the heterogeneous training set algorithm, which includes information on more than 1.3 million known biologically active compounds that correlates with the data on about 10,000 types of biological activity [122]. Chemical descriptors implemented in PASS, which reflect the peculiarities of ligand-target interactions, and the original realization of the Bayesian approach for the elucidation of structure-activity relationships provide the average accuracy and predictivity for several thousand biological activities equal to about $96 \%$ [123]. In several comparative studies, it was shown that PASS outperforms, in predictivity, some other recently developed methods for the estimation of biological activity profiles $[124,125]$. Freely available via the Internet, the PASS Online web-service [126] is used by more than thirty thousand researchers from almost a hundred countries to determine the most promising biological activities for both natural and synthetic compounds [127,128]. To reveal the hidden pharmacological potential of the natural substances, researchers have successfully used the past fifteen years [129,130].

In the current study, we obtained PASS predictions for about 60 saturated fatty acids produced by different living organisms. PASS estimates are presented as Pa values, which correspond to the probability of belonging to a class of "actives" for each predicted biological activity. The higher the Pa value, the higher the confidence in the predicted biological activity [131].

Saturated FA (1-13) are complex lipids and are found in almost all living organisms. The biological activities of some of these acids have been studied and are shown in Table 1. The biological activity that was found using the PASS program is also provided in Table 1. For all saturated acids, the property as a regulator of lipid metabolism is dominant with a reliability of $86 \%$ to $91 \%$. Of greatest interest are acids $\mathbf{9 , 1 0 , 1 1}$, and $\mathbf{1 2}$ since their reliability exceeds $91 \%$ and Figure 16 shows the 3D graph of the predicted and calculated biological activity of these saturated FA. 
Table 1. Biological activity of saturated FA.

\begin{tabular}{|c|c|c|c|}
\hline No. & Predicted Biological Activity, $\mathbf{P a}$ * & Reported Activity & Ref. \\
\hline 1 & $\begin{array}{c}\text { Lipid metabolism regulator }(0.860), \text { Antiviral (Arbovirus) }(0.833) \\
\text { Anti-inflammatory }(0.709), \text { Antiviral (Picornavirus) }(0.706) \\
\text { Anti-hypercholesterolemic }(0.646), \text { Antibacterial }(0.638) \\
\text { Atherosclerosis treatment }(0.634), \\
\text { Antiprotozoal (Coccidial) }(0.514)\end{array}$ & $\begin{array}{l}\text { Antibacterial } \\
\text { Anti-fungal } \\
\text { Anti-protozoan } \\
\text { Antiviral }\end{array}$ & [132] \\
\hline 2 & $\begin{array}{l}\text { Lipid metabolism regulator (0.860), Antiviral (Arbovirus) (0.833) } \\
\text { Anti-inflammatory (0.709), Antiviral (Picornavirus) (0.706) } \\
\text { Anti-hypercholesterolemic (0.646), Antibacterial (0.638) } \\
\text { Atherosclerosis treatment (0.634), Antiprotozoal (Coccidial) (0.514) }\end{array}$ & $\begin{array}{l}\text { Antibacterial } \\
\text { Anti-protozoan } \\
\text { Anti-fungal } \\
\text { Antiviral }\end{array}$ & [132] \\
\hline 3 & $\begin{array}{l}\text { Lipid metabolism regulator (0.860), Antiviral (Arbovirus) }(0.833) \\
\text { Anti-inflammatory (0.709), Antiviral (Picornavirus) }(0.706) \\
\text { Anti-hypercholesterolemic (0.646), Antibacterial (0.638) }\end{array}$ & $\begin{array}{l}\text { Antibacterial } \\
\text { Anti-fungal } \\
\text { Anti-protozoan }\end{array}$ & [132] \\
\hline 4 & $\begin{array}{l}\text { Lipid metabolism regulator (0.860), Antiviral (Arbovirus) (0.833) } \\
\text { Anti-inflammatory (0.709), Antiviral (Picornavirus) (0.706) } \\
\text { Anti-hypercholesterolemic (0.646), Antibacterial (0.638) }\end{array}$ & $\begin{array}{c}\text { Antibacterial } \\
\text { Antiviral }\end{array}$ & [132] \\
\hline 5 & $\begin{array}{l}\text { Lipid metabolism regulator (0.860), Antiviral (Arbovirus) }(0.833) \\
\text { Anti-inflammatory (0.709), Antiviral (Picornavirus) }(0.706) \\
\text { Anti-hypercholesterolemic (0.646), Antibacterial }(0.638)\end{array}$ & $\begin{array}{l}\text { Antibacterial } \\
\text { Anti-fungal }\end{array}$ & [132] \\
\hline 6 & $\begin{array}{c}\text { Lipid metabolism regulator (0.860), Antiviral (Arbovirus) (0.833) } \\
\text { Anti-inflammatory (0.709), Antiviral (Picornavirus) (0.706) } \\
\text { Anti-hypercholesterolemic (0.646), Antibacterial (0.638) }\end{array}$ & Antibacterial & [132] \\
\hline 7 & $\begin{array}{c}\text { Preneoplastic conditions treatment (0.836), Antiviral (Arbovirus) (0.833) } \\
\text { Anti-inflammatory (0.709), Antiviral (Picornavirus) (0.706) } \\
\text { Anti-hypercholesterolemic (0.646), Antibacterial (0.638) }\end{array}$ & $\begin{array}{l}\text { Antibacterial } \\
\text { Anticancer }\end{array}$ & {$[132,133]$} \\
\hline 8 & $\begin{array}{c}\text { Lipid metabolism regulator (0.860), Antiviral (Arbovirus) (0.833) } \\
\text { Anti-inflammatory (0.709), Antiviral (Picornavirus) (0.706) } \\
\text { Anti-hypercholesterolemic (0.646), Antibacterial (0.638) }\end{array}$ & $\begin{array}{c}\text { Antibacterial } \\
\text { Anti-breast cancer }\end{array}$ & {$[132,134]$} \\
\hline 9 & $\begin{array}{c}\text { Lipid metabolism regulator (0.913), Hypolipemic }(0.768) \\
\text { Acute neurologic disorders treatment (0.718), Anticonvulsant }(0.717) \\
\text { Antiviral (Arbovirus) (0.705), Antiviral (Picornavirus) }(0.617)\end{array}$ & $\begin{array}{l}\text { Antibacterial } \\
\text { Antiviral } \\
\text { Hemolytic }\end{array}$ & [132] \\
\hline
\end{tabular}

Lipid metabolism regulator (0.913), Hypolipemic (0.768)

10 Acute neurologic disorders treatment (0.718), Anticonvulsant (0.717) Antiviral (Arbovirus) (0.705), Antiviral (Picornavirus) (0.617)

No experimental data

Lipid metabolism regulator (0.913), Hypolipemic (0.768)

11 Acute neurologic disorders treatment (0.718), Anticonvulsant (0.717)

No experimental data Antiviral (Arbovirus) (0.705), Antiviral (Picornavirus) (0.617)

Lipid metabolism regulator (0.913), Hypolipemic (0.768)

Antiviral (Arbovirus) (0.705), Antiviral (Picornavirus) (0.617)

Lipid metabolism regulator (0.817), Hypolipemic (0.784)

Antiviral (Arbovirus) (0.768), Antineurotic (0.752)

Antiviral (Picornavirus) (0.683), Antifungal (0.567)

No experimental data

* Only activities with $\mathrm{Pa}>0.5$ are shown.

It is known that iso-FA (14-26), which are part of complex lipids and are found in almost all living organisms, are produced by many bacteria. The biological activity of some of these acids was studied and shown in Table 2, and the structures are shown in Figure 2. The biological activity that was found using the PASS program is provided in Table 2. For many iso-acids, the dominant property is as a regulator of lipid metabolism with a reliability of more than $81 \%$. Among the published activities of iso-acids, anti-breast cancer activity is characteristic. Three acids 17, 18 and 19 are of interest since their reliability is 
$81 \%$ and Figure 17 provides the 3D graph of the predicted and calculated biological activity of these FA.

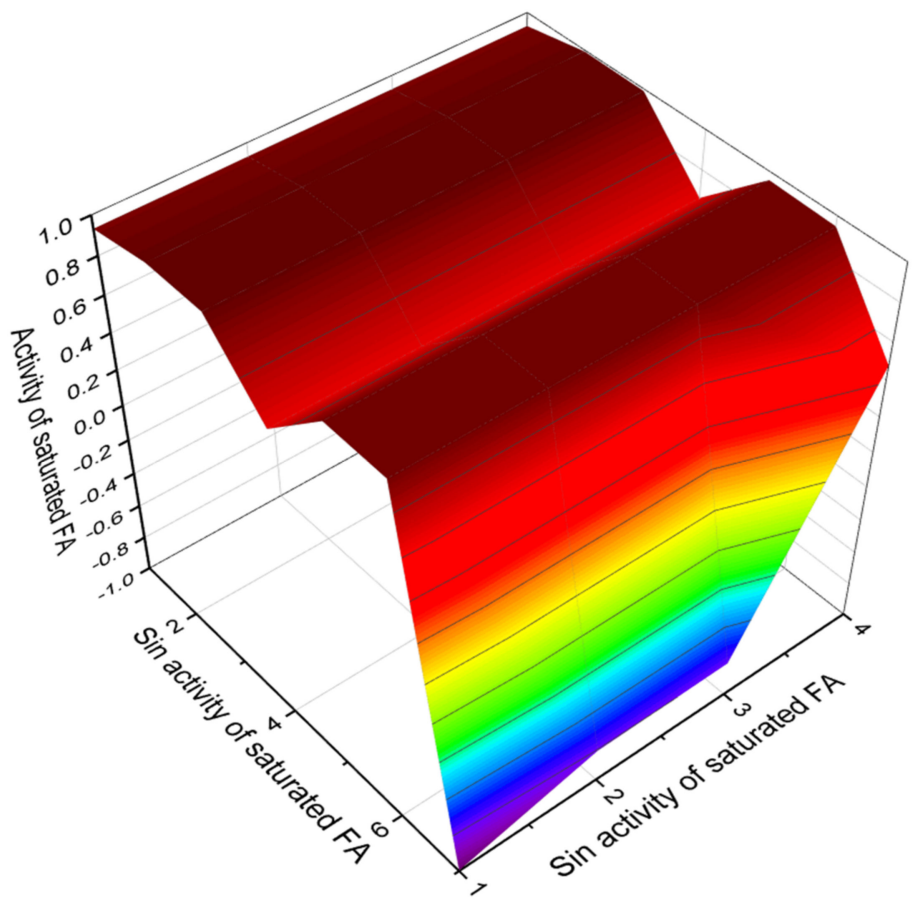

Figure 16. The $3 \mathrm{D}$ graph shows the predicted and calculated biological activity of saturated FA (compound numbers: $\mathbf{9}, \mathbf{1 0}, \mathbf{1 1}$, and 12) showing the highest degree of confidence of more than $91 \%$. The red zone is the dominant activity that is characteristic of all acids.

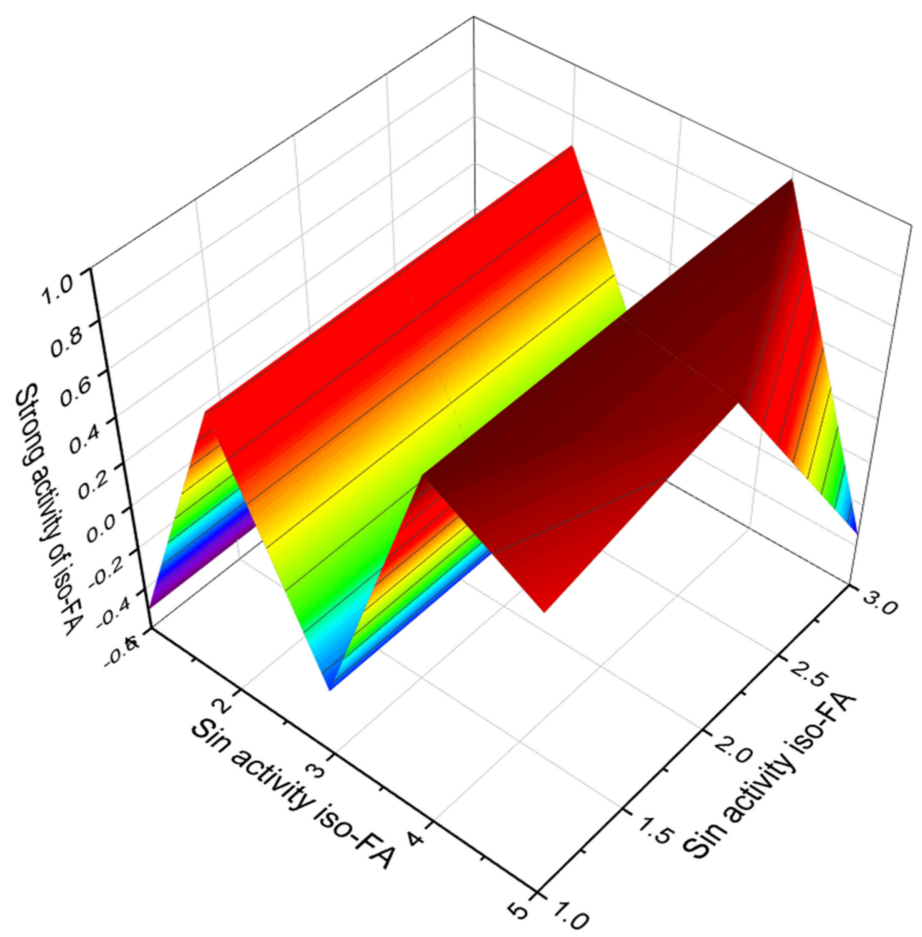

Figure 17. The 3D graph shows the predicted and calculated biological activity of iso-FA (compound numbers: 17, 18, and 19) showing the highest degree of confidence, more than $81 \%$. In the red zone, there are two dominant activities (two peaks), which are characteristic of these acids. The first property is a regulator of lipid metabolism with a confidence level of $81 \%$, and the second property is the treatment of precancerous conditions with a confidence level of more than $80 \%$. 
Table 2. Biological activity of acyclic aliphatic iso-FA.

\begin{tabular}{|c|c|c|c|}
\hline No. & Predicted Biological Activity, Pa * & Reported Activity & Ref. \\
\hline 14 & $\begin{array}{c}\text { Sclerosant }(0.878), \text { Anesthetic general }(0.849) \\
\text { Lipid metabolism regulator }(0.810), \\
\text { Preneoplastic conditions treatment }(0.805) \\
\text { Acute neurologic disorders treatment }(0.723), \\
\text { Antiviral (Arbovirus) (0.716), Antiviral (Picornavirus) (0.649) }\end{array}$ & No experimental data & \\
\hline 15 & $\begin{array}{c}\text { Sclerosant (0.878), Anesthetic general }(0.849) \\
\text { Lipid metabolism regulator }(0.810), \\
\text { Preneoplastic conditions treatment }(0.805) \\
\text { Acute neurologic disorders treatment }(0.723), \\
\text { Antiviral (Arbovirus) (0.716), Antiviral (Picornavirus) (0.649) }\end{array}$ & No experimental data & \\
\hline 16 & $\begin{array}{c}\text { Sclerosant }(0.878), \text { Anesthetic general }(0.849) \\
\text { Lipid metabolism regulator }(0.810), \\
\text { Preneoplastic conditions treatment }(0.805) \\
\text { Acute neurologic disorders treatment }(0.723), \\
\text { Antiviral (Arbovirus) (0.716), Antiviral (Picornavirus) (0.649) }\end{array}$ & Anti-breast cancer & {$[134,135]$} \\
\hline 17 & $\begin{array}{c}\text { Lipid metabolism regulator }(0.810) \\
\text { Preneoplastic conditions treatment }(0.805) \\
\text { Antiviral (Arbovirus) (0.716), Antiviral (Picornavirus) (0.649) }\end{array}$ & Anti-breast cancer & {$[134,135]$} \\
\hline 18 & $\begin{array}{c}\text { Lipid metabolism regulator }(0.810) \\
\text { Preneoplastic conditions treatment }(0.805) \\
\text { Antiviral (Arbovirus) (0.716), Antiviral (Picornavirus) (0.649) }\end{array}$ & Anti-breast cancer & [134] \\
\hline 19 & $\begin{array}{c}\text { Lipid metabolism regulator }(0.810) \\
\text { Preneoplastic conditions treatment }(0.805) \\
\text { Antiviral (Arbovirus) (0.716), Antiviral (Picornavirus) (0.649) }\end{array}$ & Anti-breast cancer & {$[134,135]$} \\
\hline 20 & $\begin{array}{c}\text { Lipid metabolism regulator (0.810), Antiviral (Arbovirus) (0.716), } \\
\text { Antiviral (Picornavirus) (0.649) }\end{array}$ & & \\
\hline 21 & $\begin{array}{c}\text { Lipid metabolism regulator }(0.810), \\
\text { Preneoplastic conditions treatment }(0.805), \\
\text { Antiviral (Arbovirus) (0.716), Antiviral (Picornavirus) (0.649) }\end{array}$ & Anti-breast cancer & {$[134,135]$} \\
\hline 22 & $\begin{array}{c}\text { Lipid metabolism regulator }(0.810) \\
\text { Preneoplastic conditions treatment }(0.805) \\
\text { Antiviral (Arbovirus) (0.716), Antiviral (Picornavirus) (0.649) }\end{array}$ & Anti-breast cancer & [134] \\
\hline 23 & $\begin{array}{c}\text { Lipid metabolism regulator (0.810), } \\
\text { Preneoplastic conditions treatment (0.805), } \\
\text { Antiviral (Arbovirus) (0.716), Antiviral (Picornavirus) (0.649) }\end{array}$ & Anti-breast cancer & [134] \\
\hline 24 & $\begin{array}{c}\text { Lipid metabolism regulator }(0.810) \\
\text { Preneoplastic conditions treatment }(0.805) \\
\text { Antiviral (Arbovirus) (0.716), Antiviral (Picornavirus) (0.649) }\end{array}$ & Anti-breast cancer & [134] \\
\hline 25 & $\begin{array}{c}\text { Preneoplastic conditions treatment (0.805), } \\
\text { Antiviral (Arbovirus) (0.716), Antiviral (Picornavirus) (0.649), } \\
\text { Antimutagenic (0.532) }\end{array}$ & No experimental data & \\
\hline 26 & $\begin{array}{c}\text { Preneoplastic conditions treatment (0.805), } \\
\text { Antiviral (Arbovirus) (0.716), Antiviral (Picornavirus) (0.649), } \\
\text { Antimutagenic (0.532) }\end{array}$ & No experimental data & \\
\hline
\end{tabular}

* Only activities with $\mathrm{Pa}>0.5$ are shown.

Anteiso-FA (27-39), which are part of complex lipids, are found in almost all living organisms, and many bacteria produce them in significant quantities. The biological activity that was found using the PASS program is shown in Table 3, and the structures are shown in Figure 2. For many anteiso-acids, the dominant property is as a regulator of lipid metabolism with a confidence level of more than 91\%. Of interest are four acids 30, 31, 35, and 39, and the reliability of their activity is more than $91 \%$, and Figure 18 represents the $3 \mathrm{D}$ graph of the predicted and calculated biological activity of these anteiso-FA. 
Table 3. Biological activity of acyclic aliphatic anteiso-FA.

\begin{tabular}{|c|c|}
\hline No. & Predicted Biological Activity, Pa * \\
\hline 27 & $\begin{array}{l}\text { Anti-hypercholesterolemic }(0.801) \text {, Preneoplastic conditions treatment }(0.793) \\
\text { Hypolipemic }(0.768) \text {, Acute neurologic disorders treatment }(0.718) \\
\text { Atherosclerosis treatment }(0.679) \text {, Antineoplastic }(0.566) \text {, Antiparasitic }(0.526)\end{array}$ \\
\hline 28 & $\begin{array}{l}\text { Anti-hypercholesterolemic }(0.801) \text {, Preneoplastic conditions treatment }(0.793) \\
\text { Hypolipemic }(0.768) \text {, Acute neurologic disorders treatment }(0.718) \\
\text { Atherosclerosis treatment }(0.679) \text {, Antineoplastic }(0.566) \text {, Antiparasitic }(0.526)\end{array}$ \\
\hline 29 & $\begin{array}{l}\text { Anti-hypercholesterolemic }(0.801) \text {, Preneoplastic conditions treatment }(0.793) \\
\text { Hypolipemic }(0.768) \text {, Acute neurologic disorders treatment }(0.718) \\
\text { Atherosclerosis treatment }(0.679) \text {, Antineoplastic }(0.566) \text {, Antiparasitic }(0.526)\end{array}$ \\
\hline 30 & $\begin{array}{c}\text { Lipid metabolism regulator (0.913), Anti-hypercholesterolemic (0.801); Hypolipemic (0.768) } \\
\text { Acute neurologic disorders treatment (0.718), Anticonvulsant (0.717) } \\
\text { Atherosclerosis treatment (0.679), Antifungal (0.592), Antiparasitic (0.526) }\end{array}$ \\
\hline 31 & $\begin{array}{l}\text { Lipid metabolism regulator (0.913), Anti-hypercholesterolemic (0.801), Hypolipemic (0.768) } \\
\text { Acute neurologic disorders treatment (0.718), Anticonvulsant (0.717) } \\
\text { Atherosclerosis treatment (0.679), Antifungal (0.592), Antiparasitic (0.526) }\end{array}$ \\
\hline 32 & $\begin{array}{l}\text { Lipid metabolism regulator (0.913), Anti-hypercholesterolemic (0.801), Hypolipemic (0.768) } \\
\text { Acute neurologic disorders treatment (0.718), Anticonvulsant (0.717) } \\
\text { Atherosclerosis treatment (0.679), Antifungal (0.592), Antiparasitic }(0.526)\end{array}$ \\
\hline 33 & $\begin{array}{l}\text { Lipid metabolism regulator (0.913), Anti-hypercholesterolemic (0.801), Hypolipemic }(0.768) \\
\text { Acute neurologic disorders treatment (0.718), Anticonvulsant (0.717) } \\
\text { Atherosclerosis treatment (0.679), Antifungal (0.592), Antiparasitic }(0.526)\end{array}$ \\
\hline 34 & $\begin{array}{c}\text { Lipid metabolism regulator (0.913), Anti-hypercholesterolemic (0.801), Hypolipemic }(0.768) \\
\text { Acute neurologic disorders treatment (0.718); Anticonvulsant (0.717) } \\
\text { Atherosclerosis treatment (0.679), Antifungal (0.592), Antiparasitic (0.526) }\end{array}$ \\
\hline 35 & $\begin{array}{c}\text { Lipid metabolism regulator (0.913), Anti-hypercholesterolemic }(0.801) \text {, Hypolipemic }(0.768) \\
\text { Atherosclerosis treatment }(0.679) \text {, Antifungal }(0.592) \text {, Antiparasitic }(0.526)\end{array}$ \\
\hline 36 & $\begin{array}{c}\text { Lipid metabolism regulator (0.913), Anti-hypercholesterolemic }(0.801) \text {, Hypolipemic }(0.768) \\
\text { Atherosclerosis treatment (0.679), Antifungal (0.592), Antiparasitic (0.526) }\end{array}$ \\
\hline 37 & $\begin{array}{l}\text { Lipid metabolism regulator (0.913), Anti-hypercholesterolemic }(0.801) \text {, Hypolipemic }(0.768) \\
\text { Atherosclerosis treatment (0.679), Antifungal (0.592), Antiparasitic }(0.526)\end{array}$ \\
\hline 38 & $\begin{array}{c}\text { Lipid metabolism regulator (0.913), Anti-hypercholesterolemic }(0.801) \text {, Hypolipemic }(0.768) \\
\text { Atherosclerosis treatment (0.679), Antifungal (0.592), Antiparasitic (0.526) }\end{array}$ \\
\hline 39 & $\begin{array}{l}\text { Lipid metabolism regulator (0.913), Anti-hypercholesterolemic (0.801), Hypolipemic }(0.768) \\
\text { Acute neurologic disorders treatment (0.718), Anticonvulsant (0.717) } \\
\text { Atherosclerosis treatment (0.679), Antifungal (0.592), Antiparasitic (0.526) }\end{array}$ \\
\hline
\end{tabular}

Methyl-branched and cyclic FA (40-59), which are complex lipids, are found in many aquatic organisms including marine and freshwater sponges, molluscs, and other organisms. Bacteria produce cyclic FA. The biological activity that was found using the PASS program is shown in Table 4, whereas the structures are shown in Figure 3. Of greater interest are two cyclic FA (58 and 59) that have been shown to prevent the growth of blood clots and break down blood clots. This is a rare property that FA 58 and $\mathbf{5 9}$ exhibit. Figure 19 provides the 3D graph of the predicted and calculated biological activity of cyclic FA. 


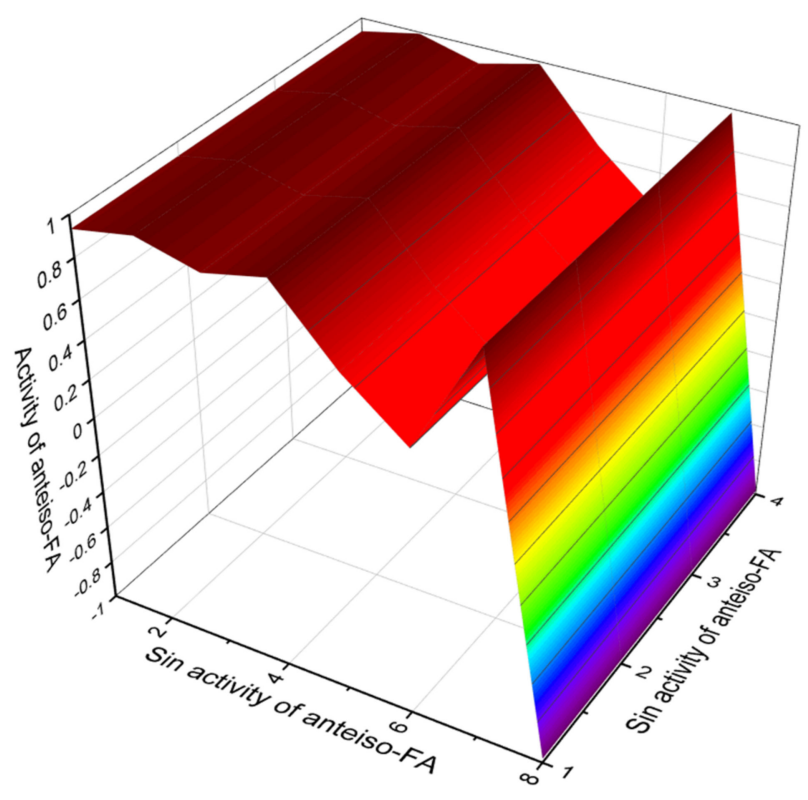

Figure 18. 3D graph showing the predicted and calculated biological activity of anteiso-FA (compound numbers: 30, 31, 35, and 39) showing the highest degree of confidence of more than $91 \%$.

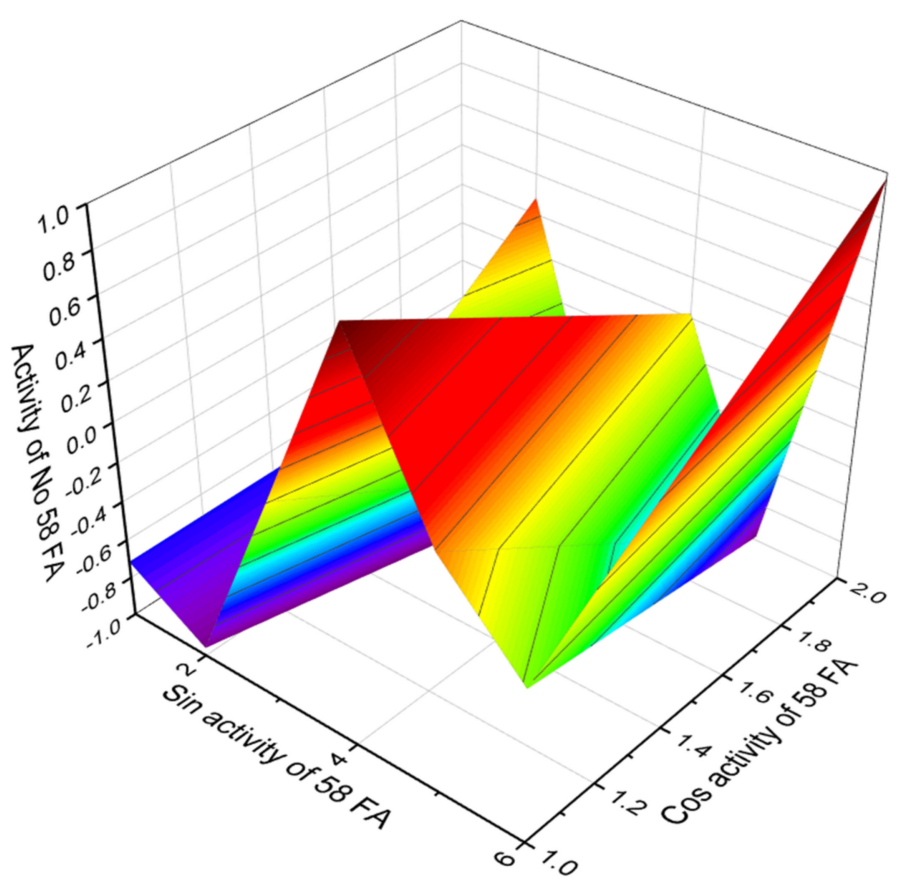

Figure 19. $3 \mathrm{D}$ graph showing the predicted and calculated biological activity of $\omega$-cyclo-17,11cyclohexyl undecanoic acid (58, cyclohexyl 16:0) with the highest degree of confidence of more than 91\%. Both $\omega$-cyclohexyl FA (58 and 59) were found in two strains of Curtobacterium pusillum and other strains of the genus Alicyclobacillus. w-Cyclohexyl undecanoic acid (58) constituted 12\% to $96 \%$ of the total FA in the bacteria [136-138]. 
Table 4. Biological activity of methyl-branched and cyclic FA.

\begin{tabular}{|c|c|}
\hline No. & Predicted Biological Activity, Pa * \\
\hline 40 & $\begin{array}{l}\text { Lipid metabolism regulator (0.905), } \\
\text { Anti-hypercholesterolemic (0.789), Hypolipemic (0.757) }\end{array}$ \\
\hline 41 & $\begin{array}{c}\text { Lipid metabolism regulator }(0.817) \text {, Anti-hypercholesterolemic }(0.674) \\
\text { Atherosclerosis treatment }(0.643)\end{array}$ \\
\hline 42 & $\begin{array}{l}\text { Lipid metabolism regulator }(0.905) \text {, Anti-hypercholesterolemic (0.789) } \\
\text { Atherosclerosis treatment }(0.682)\end{array}$ \\
\hline 43 & $\begin{array}{l}\text { Lipid metabolism regulator }(0.853) \text {, Hypolipemic }(0.767) \\
\text { Anti-hypercholesterolemic }(0.699) \text {, Atherosclerosis treatment }(0.694)\end{array}$ \\
\hline 44 & $\begin{array}{l}\text { Hypolipemic }(0.863) \text {, Lipid metabolism regulator }(0.803) \\
\text { Atherosclerosis treatment }(0.655) \text {, Anti-hypercholesterolemic }(0.610)\end{array}$ \\
\hline 45 & $\begin{array}{l}\text { Lipid metabolism regulator }(0.877) \text {, Hypolipemic }(0.809) \\
\text { Atherosclerosis treatment }(0.701) \text {, Anti-hypercholesterolemic }(0.656)\end{array}$ \\
\hline 46 & $\begin{array}{l}\text { Lipid metabolism regulator }(0.877) \text {, Hypolipemic }(0.809) \\
\text { Atherosclerosis treatment }(0.701) \text {, Anti-hypercholesterolemic }(0.656)\end{array}$ \\
\hline 47 & $\begin{array}{l}\text { Lipid metabolism regulator }(0.877) \text {; Hypolipemic }(0.809) \\
\text { Atherosclerosis treatment }(0.701) \text {, Anti-hypercholesterolemic }(0.656)\end{array}$ \\
\hline 48 & $\begin{array}{l}\text { Lipid metabolism regulator }(0.865) \text {, Hypolipemic }(0.781) \\
\text { Anti-hypercholesterolemic }(0.721) \text {, Atherosclerosis treatment }(0.659)\end{array}$ \\
\hline 49 & $\begin{array}{c}\text { Lipid metabolism regulator }(0.854) \text {, Anti-hypercholesterolemic }(0.766) \\
\text { Hypolipemic }(0.740) \text {, Atherosclerosis treatment }(0.685)\end{array}$ \\
\hline 50 & $\begin{array}{c}\text { Lipid metabolism regulator (0.860), Anti-hypercholesterolemic }(0.790) \\
\text { Hypolipemic }(0.769) \text {, Atherosclerosis treatment }(0.692)\end{array}$ \\
\hline 51 & $\begin{array}{l}\text { Hypolipemic }(0.833) \text {, Acute neurologic disorders treatment }(0.830) \\
\text { Lipid metabolism regulator }(0.771) \text {, Anti-hypercholesterolemic }(0.701) \\
\text { Atherosclerosis treatment }(0.698) \text {, Anti-inflammatory }(0.662)\end{array}$ \\
\hline 52 & $\begin{array}{l}\text { Lipid metabolism regulator }(0.790) \\
\text { Anti-hypercholesterolemic }(0.757), \text { Hypolipemic }(0.677)\end{array}$ \\
\hline 53 & $\begin{array}{l}\text { Lipid metabolism regulator }(0.854) \text {, Anesthetic general }(0.793) \\
\text { Anti-hypercholesterolemic }(0.766) \text {, Hypolipemic }(0.740)\end{array}$ \\
\hline 54 & $\begin{array}{l}\text { Hypolipemic }(0.833), \text { Acute neurologic disorders treatment }(0.830) \\
\text { Lipid metabolism regulator }(0.771) \text {, Neuroprotector }(0.676)\end{array}$ \\
\hline 55 & $\begin{array}{l}\text { Mucositis treatment }(0.842) \text {, Fibrinolytic }(0.821) \\
\text { Antithrombotic }(0.635), \text { Antimutagenic }(0.566)\end{array}$ \\
\hline 56 & $\begin{array}{l}\text { Anti-eczematic (0.893), Mucositis treatment }(0.842) \\
\text { Fibrinolytic }(0.821) \text {, Anti-inflammatory }(0.704)\end{array}$ \\
\hline 57 & $\begin{array}{l}\text { Anti-eczematic (0.893), Mucositis treatment }(0.842) \\
\text { Fibrinolytic }(0.821), \text { Anti-inflammatory }(0.704)\end{array}$ \\
\hline 58 & $\begin{array}{l}\text { Fibrinolytic (0.915), Cardiovascular analeptic (0.715), Antithrombotic (0.688) } \\
\text { Anti-ischemic, cerebral (0.655), Platelet antagonist (0.581), Anticoagulant (0.515) }\end{array}$ \\
\hline 59 & $\begin{array}{l}\text { Fibrinolytic (0.915), Cardiovascular analeptic }(0.715) \text {, Antithrombotic }(0.688) \\
\text { Anti-ischemic, cerebral (0.655), Platelet antagonist }(0.581) \text {, Anticoagulant }(0.515)\end{array}$ \\
\hline
\end{tabular}

\section{Conclusions}

This review focused on the hydrobiological aspects of saturated, methyl-branched, and cyclic FA derived from aquatic ecosystems and their distribution. The review presents about 60 that are found in various living organisms as well as in marine and freshwater sediments such as rivers, lakes, and sea bays. Particularly interesting was the determination of the biological activity of saturated, methyl-branched, and cyclic FA. The pharmacological 
activity of the presented acids was determined using the popular computer program PASS. According to PASS data, saturated FA are of interest as regulators of lipid metabolism as well as processes associated with the metabolism and synthesis of cholesterol. In addition, some acids exhibited antiviral and other properties. Methyl-branched acids exhibited similar properties. Interestingly, some cyclic FA exhibited antiplatelet, fibrinolytic, and anticoagulant activities. The obtained and presented data are of interest to hydrobiologists, biologists, chemists, and pharmacologists.

Funding: This work did not receive any specific grant from funding agencies in the public, commercial, or not-for-profit sectors.

Institutional Review Board Statement: Not applicable.

Informed Consent Statement: Not applicable.

Data Availability Statement: Not applicable.

Acknowledgments: The author is grateful to Tatyana A. Gloriozova (Institute of Biomedical Chemistry, Moscow, Russia) for prompt help in determining the biological activity of FA presented in the article.

Conflicts of Interest: The author declares that he has no known competing financial interest or personal relationships that could affect the work described in this article.

\section{References}

1. Ackman, R.A. Marine Biogenic Lipids, Fats E Oils; CRC Press: Boca Raton, FL, USA, 1989; Volume 1.

2. Eoin, F.; Shankar, S.; Brown, H.A.; Glass, C.K.; Merrill, A.H., Jr. A comprehensive classification system for lipids. J. Lipid Res. 2005, 46, 839-861.

3. Cassim, A.M.; Gouguet, P.; Gronnier, J.; Laurent, N. Plant lipids: Key players of plasma membrane organization and function. Prog. Lipid Res. 2019, 73, 1-27. [CrossRef] [PubMed]

4. Peterson, B.L.; Cummings, B.S. A review of chromatographic methods for the assessment of phospholipids in biological samples. Biomed. Chromatogr. 2006, 20, 227-243. [CrossRef] [PubMed]

5. Suzumura, M. Phospholipids in marine environments: A review. Talanta 2005, 66, 422-434. [CrossRef]

6. Motolese, P. Phospholipids do not have lipolytic activity. A critical review. J. Cosmet. Laser Ther. 2008, 10, 114-118. [CrossRef]

7. Laufs, U.; Parhofer, K.G.; Ginsberg, H.N.; Hegele, R.A. Clinical review on triglycerides. Eur. Heart J. 2020, 41, 99-109. [CrossRef]

8. Dembitsky, V.M.; Srebnik, M. Natural halogenated fatty acids: Their analogues and derivatives. Prog. Lipid Res. 2002, 41, 315-367. [CrossRef]

9. Brockerhoff, H. Stereospecific analysis of triglycerides. Lipids 1971, 6, 942-956. [CrossRef]

10. Li, J.; Wang, X.; Zhang, T.; Wang, C.; Huang, Z.; Luo, X. A review on phospholipids and their main applications in drug delivery systems. Asian J. Pharm. Sci. 2015, 10, 81-98. [CrossRef]

11. Ball, W.B.; Neff, J.K.; Gohil, V.M. The role of nonbilayer phospholipids in mitochondrial structure and function. FEBS Lett. 2018, 592, 1273-1290. [CrossRef]

12. Dyas, L.; Goad, L.J. Steryl fatty acyl esters in plants. Phytochemistry 1993, 34, 17-29. [CrossRef]

13. Taylor, L.A.; Pletschen, L.; Arends, J. Marine phospholipids-A promising new dietary approach to tumor-associated weight loss. Support Care Cancer 2010, 18, 159-167. [CrossRef]

14. Colin, L.A.; Jaillais, Y. Phospholipids across scales: Lipid patterns and plant development. Curr. Opin. Plant Biol. 2020, 53, 1-9. [CrossRef]

15. Pundir, C.S.; Narwal, V. Biosensing methods for determination of triglycerides: A review. Biosens. Bioelectron. 2018, 100, $214-227$. [CrossRef]

16. Rahim, N.; Ahmat, N.; Norrizah, J.S.; Aripin, N.F.K. A review on phase behaviour of glycolipids derived from plants. Materials Today Proceed. 2018, 5, S180-S185. [CrossRef]

17. Vial, H.J.; Eldin, P.; Tielens, A.G.M.; van Hellemond, J.J. Phospholipids in parasitic protozoa. Mol. Biochem. Parasitol. 2003, 126, 143-154. [CrossRef]

18. Guschina, I.A.; Harwood, J.L. Lipids and lipid metabolism in eukaryotic algae. Prog. Lipid Res. 2006, 45, 160-186. [CrossRef]

19. Simon, E.W. Phospholipids and plant membrane permeability. New Phytol. 1974, 73, 377-420. [CrossRef]

20. Thompson, G.A., Jr.; Nozawa, Y. Lipids of protozoa: Phospholipids and neutral lipids. Ann. Rev. Microbiol. 1972, 26, 249-278. [CrossRef]

21. Working, E.B.; Andrews, A.C. The structure of the phospholipids. Chem. Rev. 1941, 29, 245-256. [CrossRef]

22. Nakamura, Y. Plant phospholipid diversity: Emerging functions in metabolism and protein-lipid interactions. Trends Plant Sci. 2017, 22, 1027-1040. [CrossRef]

23. Liu, B.; Benning, C. Lipid metabolism in microalgae distinguishes itself. Curr. Opin. Biotechnol. 2013, 24, 300-309. [CrossRef] [PubMed] 
24. Bellou, S.; Baeshen, M.N.; Elazzazy, A.M.; Aggeli, D. Microalgal lipids biochemistry and biotechnological perspectives. Biotechnol. Adv. 2014, 32, 1476-1493. [CrossRef] [PubMed]

25. Dembitsky, V.M. Natural neo acids and neo alkanes: Their analogues and derivatives. Lipids 2006, 41, 309-340. [CrossRef] [PubMed]

26. Fonseca, C.R.; Bordin, K.; Fernandes, A.M.; Rodrigues, C.E.C.; Corassin, C.H.; Cruz, A.G.; Oliveira, C.A.F. Storage of refrigerated raw goat milk affecting the quality of whole milk powder. J. Dairy Sci. 2013, 96, 4716-4724. [CrossRef]

27. Ribeiro, A.C.; Ribeiro, S.D.A. Specialty products made from goat milk. Small Ruminant Res. 2010, 89, 225-233. [CrossRef]

28. Kaneda, T. Iso- and anteiso-fatty acids in bacteria: Biosynthesis, function, and taxonomic significance. Microbiol. Rev. 1991, 41, 288-302. [CrossRef]

29. Kaneda, T. Fatty acids in the genus Bacillus. I. Iso- and anteiso-fatty acids as characteristic constituents of lipids in 10 species. J. Bacteriol. 1967, 93, 894-903. [CrossRef]

30. Pedneault, K.; Angers, P.; Gosselin, A.; Tweddell, R.J. Fatty acid composition of lipids from mushrooms belonging to the family Boletaceae. Mycol. Res. 2006, 110, 1179-1183. [CrossRef]

31. Moore, B.S.; Floss, H.G. Biosynthesis of cyclic fatty acid containing cyclopropyl, cyclopentyl, cyclohexyl and cycloheptyl rings. Reference Module in Chemistry, Molecular Sciences, and Chemical Engineering. Comprehen. Nat. Prod. Chem. 1999, 1, 61-82.

32. Bao, X.; Katz, S.; Pollard, M.; John, O. Carbocyclic fatty acids in plants: Biochemical and molecular genetic characterization of cyclopropane fatty acid synthesis of Sterculia foetida. Plant Biol. 2002, 99, 7172-7177. [CrossRef]

33. Grogan, D.W.; Cronan, J.E., Jr. Cyclopropane ring formation in membrane lipids of bacteria. Microbiol. Mol. Biol. Rev. 1997, 14, 429-441.

34. Ortiz, A.; Sansinenea, E. Chemical compounds produced by Bacillus sp. factories and their role in nature. Mini Rev. Med. Chem. 2019, 19, 373-380. [CrossRef]

35. James, G.; Das, B.C.; Jose, S. Bacillus as an aquaculture friendly microbe. Aquacult. Int. 2021, 29, 323-353. [CrossRef]

36. Cooper, W.J.; Blumer, M. Linear, iso and anteiso fatty acids in recent sediments of the North Atlantic. Deep Sea Res. Oceanogr. Abst. 1968, 15, 535-540. [CrossRef]

37. Perry, G.J.; Volkman, J.K.; Johns, R.B.; Bavor, H.J., Jr. Fatty acids of bacterial origin in contemporary marine sediments. Geochim. Cosmochim. Acta 1979, 43, 1715-1725. [CrossRef]

38. Opris, S.; Sicora, C.; Rusu, T.; Miclean, M. Identification and quantification of fatty acids in cyanobacteria cells. ProEnvironment 2013, 6, 402-406.

39. Ötleş, S.; Pire, R. Fatty acid composition of Chlorella and Spirulina microalgae species. J. AOAC Int. 2001, 84, 1708-1714. [CrossRef]

40. Ǩezanka, T.; Dor, I.; Prell, A.; Dembitsky, V.M. Fatty acid composition of six freshwater wild cyanobacterial species. Folia Microbiol. 2003, 48, 71-75. [CrossRef]

41. Rezanka, T.; Víden, I.; Go, J.V.; Dor, I.; Dembitsky, V.M. Polar lipids and fatty acids of three wild cyanobacterial strains of the genus Chroococcidiopsis. Folia Microbiol. 2003, 48, 781-786. [CrossRef]

42. Temina, M.; Rezankova, H.; Rezanka, T.; Dembitsky, V.M. Diversity of the fatty acids of the Nostoc species and their statistical analysis. Microbiol. Res. 2007, 162, 308-321. [CrossRef] [PubMed]

43. Singh, S.C.; Sinha, R.P.; Hader, D.P. Role of lipids and fatty acids in stress tolerance in cyanobacteria. Acta Protozool. 2002, 41, 297-308.

44. Zahra, Z.; Choo, D.H.; Lee, H.; Parveen, A. Cyanobacteria: Review of current potentials and applications. Environments 2020, 7, 13. [CrossRef]

45. Ananya, A.K.; Ahmad, I.Z. Cyanobacteria "the blue green algae" and its novel applications: A brief review. Int. J. Innov. Appl. Stud. 2014, 7, 251-261.

46. Kong, F.; Romero, I.T.; Warakanont, J. Lipid catabolism in microalgae. New Phytol. 2018, 218, 1340-1348. [CrossRef]

47. Katiyar, R.; Arora, A. Health promoting functional lipids from microalgae pool: A review. Algal Res. 2020, 46, 101800. [CrossRef]

48. Dembitsky, V.M.; Srebnik, M. Variability of hydrocarbon and fatty acid components in cultures of the filamentous cyanobacterium Scytonema sp. isolated from microbial community 'Black Cover' of limestone walls in Jerusalem. Biochemistry 2002, 67, 1276-1282.

49. Dembitsky, V.M.; Dor, I.; Shkrob, I. Variability of lipid constituents of the soil cyanobacterium Microcoleus vaginatus from the Dead Sea basin and Negev Desert. Biochemistry 2000, 65, 1403-1408.

50. Du, X.; Liu, H.; Yuan, L.; Wang, Y.; Ma, Y.; Wang, R.; Chen, X. The diversity of cyanobacterial toxins on structural characterization, distribution, and identification: A Systematic Review. Toxins 2019, 11, 530. [CrossRef]

51. Nunnery, J.K.; Mevers, E.; Gerwick, W.H. Biologically active secondary metabolites from marine cyanobacteria. Curr. Opin. Biotechnol. 2010, 21, 787-793. [CrossRef]

52. Mnif, I.; Ghribi, D. Review lipopeptides biosurfactants: Mean classes and new insights for industrial, biomedical, and environmental applications. Peptide Sci. 2015, 104, 129-147. [CrossRef] [PubMed]

53. Siddiq, A.; Dembitsky, V. Acetylenic anticancer agents. Anti-Cancer Agents Med. Chem. 2008, 8, 132-170. [CrossRef]

54. Dembitsky, V.M.; Rozentsvet, O.A.; Pechenkina, E.E. Glycolipids, phospholipids, and fatty acids of some brown algae species from the Black Sea. Phytochemistry 1990, 29, 3417-3421. [CrossRef]

55. Dembitsky, V.M.; Rozentsvet, O.A. Phospholipid composition of some marine red algae. Phytochemistry 1990, $29,3149-3152$. [CrossRef] 
56. Dembitsky, V.M.; Pechenkina-Shubina, E.E.; Rozentsvet, O.A. Glycolipids and fatty acids of some seaweeds and marine grasses from Black Sea. Phytochemistry 1991, 30, 2279-2283. [CrossRef]

57. Harwood, J.L. Algae: Critical sources of very long-chain polyunsaturated fatty acids. Biomolecules 2019, 9, 708. [CrossRef]

58. Lu, Y.; Chen, Y.; Wu, Y.; Hao, H.; Liang, W.; Liu, J.; Huang, R. Marine unsaturated fatty acids: Structures, bioactivities, biosynthesis, and benefits. RSC Adv. 2019, 9, 35312-35327. [CrossRef]

59. Song, M.; Pham, H.D.; Seon, J.; Woo, H.C. Marine brown algae: A conundrum answer for sustainable biofuels production. Renew. Sustain. Energy Rev. 2015, 50, 782-792. [CrossRef]

60. Santos, S.; Oliveira, A.; Lopes, C. Systematic review of saturated fatty acids on inflammation and circulating levels of adipokines. Nutr. Res. 2013, 33, 687-695. [CrossRef] [PubMed]

61. Mensink, R.P. Effects of Saturated Fatty Acids on Serum Lipids and Lipoproteins: A Systematic Review and Regression Analysis; World Health Organization: Geneva, Switzerland, 2016.

62. Wood, J.D.; Richardson, R.I.; Nute, G.R.; Fisher, A.V. Effects of fatty acids on meat quality: A review. Meat Sci. 2004, 66, 21-32. [CrossRef]

63. Dembitsky, V.M.; Rezankova, H.; Rezanka, T.; Hanus, L.O. Variability of the fatty acids of the marine green algae belonging to the genus Codium. Biochem. System. Ecol. 2003, 31, 1125-1145. [CrossRef]

64. Khotimchenko, S.V. Fatty acids of species in the genus Codium. Bot. Marine 2003, 46, 456-460. [CrossRef]

65. Jerković, I.; Kranjac, M.; Marijanović, Z.; Šarkanj, B. Chemical diversity of Codium bursa (Olivi) C. Agardh headspace compounds, volatiles, fatty acids, and insight into its antifungal activity. Molecules 2019, 24, 842. [CrossRef] [PubMed]

66. El Shoubaky, G.A.; El Rahman Salem, A. Active ingredients fatty acids as antibacterial agent from the brown algae Padina pavonica and Hormophysa triquetra. J. Coast. Life Med. 2014, 2, 431-438.

67. Fleurence, J.; Gutbier, G.; Mabeaul, S.; Leray, C. Fatty acids from 11 marine macroalgae of the French Brittany coast. J. Appl. Phycol. 1994, 6, 527-532. [CrossRef]

68. Dembitsky, V.M.; Rezanka, T.; Bychek, I.A.; Afonina, O.M. Acetylenic acids and lipids of some mosses from Russia. Phytochemistry 1993, 33, 1021-1027. [CrossRef]

69. Dembitsky, V.M.; Rezanka, T.; Bychek, I.A.; Afonina, O.M. Chemical constituents of some moss species. J. Hattori Bot. Lab. 1994, $75,161-172$.

70. Dembitsky, V.M.; Rezanka, T. Distribution of diacylglycerylhomoserines, phospholipids and fatty acids in thirteen moss species from South-Western Siberia. Biochem. Syst. Ecol. 1995, 23, 71-78. [CrossRef]

71. Kornprobst, J.M.; Barnathan, G. Demospongic acids revisited. Mar. Drugs 2010, 8, 2569-2577. [CrossRef]

72. Litchfield, C.; Morales, R.W. Are demospongiae membranes unique among living organisms? In Aspects of Sponge Biology; Harrison, F.W., Cowden, R.R., Eds.; Academic Press: New York, NY, USA, 1976; pp. 183-200.

73. Carballeira, N.M. New advances in fatty acids as antimalarial, antimycobacterial and antifungal agents. Prog. Lipid Res. 2008, 47, 50-61. [CrossRef]

74. Rezanka, T.; Sigler, K. Odd-numbered very-long-chain fatty acids from the microbial, animal and plant kingdoms. Prog. Lipid Res. 2009, 48, 206-238. [CrossRef]

75. Bergé, J.P.; Barnathan, G. Fatty acids from lipids of marine organisms: Molecular biodiversity, roles as biomarkers, biologically active compounds, and economical aspects. Adv. Biochem. Eng. Biotechnol. 2005, 96, 49-125.

76. Dembitsky, V.M.; Rezanka, T.; Srebnik, M. Lipid compounds of freshwater sponges: Family Spongillidae, class Demospongiae. Chem. Physics Lipids 2003, 123, 117-155. [CrossRef]

77. Dembitsky, V.M.; Rezanka, T.; Kashin, A.G. Comparative study of the endemic freshwater fauna of Lake Baikal. 2. Unusual lipid composition of two sponges Baicalospongia bacilifera and B. intermedia (Family Lubomirskiidae, Class Demospongiae). Comp. Biochem. Physiol. 1993, 106B, 825-831.

78. Dembitsky, V.M.; Rezanka, T.; Kashin, A.G. Comparative study of the endemic freshwater fauna of Lake Baikal. 6. Unusual fatty acid and lipid composition of the endemic sponge Lubomirskia baicalensis and sponge's amphipod crustacean parasite Brandtia (Spinacantus) parasitica. Comp. Biochem. Physiol. 1994, 109B, 415-426. [CrossRef]

79. Dembitsky, V.M.; Rezanka, T. Unusually high levels of eicosatetraenoic, eicosapentaenoic and docosahexaenoic fatty acids in Palestinian freshwater sponges. Lipids 1996, 31, 647-650. [CrossRef]

80. Rezanka, T.; Dembitsky, V.M. Isoprenoid polyunsaturated fatty acids from freshwater sponges. J. Nat. Prod. 1993, 56, 1898-1904. [CrossRef]

81. Rezanka, T.; Dembitsky, V.M. Multibranched polyunsaturated and very-long-chain fatty acids of freshwater Israeli sponges. J. Nat. Prod. 2002, 65, 709-713. [CrossRef]

82. Carballeira, N.M.; Maldonado, L.; Porras, B. Isoprenoid fatty acids from marine sponges. Are sponges selective? Lipids 1987, 22, 767-769. [CrossRef]

83. Rod'kina, S.A. Fatty acids and other lipids of marine sponges. Russ. J. Mar. Biol. 2005, 31, S49-S60. [CrossRef]

84. Carballeira, N.; Thompson, J.E.; Ayanoglu, E.; Djerassi, C. Biosynthetic studies of marine lipids. 5. The biosynthesis of long-chain branched fatty acids in marine sponges. J. Org. Chem. 1986, 51, 2751-2756. [CrossRef]

85. Gillan, F.T.; Stoilov, I.L.; Thompson, J.E.; Hogg, R.W.; Wilkinson, C.R.; Djerassi, C. Fatty acids as biological markers for bacterial symbionts in sponges. Lipids 1988, 23, 1139-1145. [CrossRef] 
86. Mishra, P.M.; Sree, A.; Panda, P.K. Fatty acids of marine sponges. Fatty Acids of Marine Sponges. In Springer Handbook of Marine Biotechnology; Springer Handbooks; Kim, S.K., Ed.; Springer: Berlin, Heidelberg, 2015.

87. Pereira, M.; Vinholes, J.D.; Correia-da-Silva, G.; Valentao, P.; Teixeira, N.; Andrade, P.B. Fatty acids in marine organisms: In the Pursuit of bioactive agents. Curr. Pharm. Anal. 2011, 7, 108-119. [CrossRef]

88. Aguiar, A.C.C.; Parisi, J.R.; Granito, R.N.; de Sousa, L.R.F. Metabolites from marine sponges and their potential to treat malarial protozoan parasites infection: A Systematic Review. Mar. Drugs 2021, 19, 134. [CrossRef]

89. Mioso, R.; Marante, F.J.T.; Bezerra, R.S.; Borges, F.V.P. Cytotoxic compounds derived from marine sponges. A review (2010-2012). Molecules 2017, 22, 208. [CrossRef]

90. Kiem, P.V.; Minh, C.V.; Nhiem, N.X.; Tai, B.H. The chemical constituents and biological activity of some sponges in Northern Vietnam: A review. Vietnam J. Chem. 2019, 57, 261-271. [CrossRef]

91. Lopes-Lima, M.; Riccardi, N.; Urbanska, M. Major shortfalls impairing knowledge and conservation of freshwater molluscs. Hydrobiologia 2021, 848, 2831-2867. [CrossRef]

92. Kappes, H.; Haase, P. Slow, but steady: Dispersal of freshwater molluscs. Aquat. Sci. 2012, 74, 1-14. [CrossRef]

93. Taylor, D.W. Aspects of freshwater mollusc ecological biogeography. Palaeogeograph. Palaeoclim. Palaeoecol. 1988, 62, 511-576. [CrossRef]

94. Balian, E.V.; Segers, H.; Martens, K.; Lévéque, C. The Freshwater Animal Diversity Assessment: An Overview of the Results. In Freshwater Animal Diversity Assessment. Developments in Hydrobiology; Balian, E.V., Lévêque, C., Segers, H., Martens, K., Eds.; Springer: Dordrecht, The Netherlands, 2007; Volume 198.

95. Benkendorff, K. Molluscan biological and chemical diversity: Secondary metabolites and medicinal resources produced by marine molluscs. Biol. Rev. Camb. Philos. Soc. 2010, 85, 757-775. [CrossRef]

96. Smith, A.B. Marine diversity through the Phanerozoic: Problems and prospects. J. Geol. Soc. 2007, 164, 731-745. [CrossRef]

97. Zhukova, N.V. Fatty acids of marine mollusks: Impact of diet, bacterial symbiosis, and biosynthetic potential. Biomolecules 2019, 9, 857. [CrossRef] [PubMed]

98. Kelly, J.R.; Scheibling, R.E. Fatty acids as dietary tracers in benthic food webs. Mar. Ecol. Prog. Ser. 2012, 446, 1-22. [CrossRef]

99. Parrish, C.C. Determination of Total Lipid, Lipid Classes, and Fatty Acids in Aquatic Samples. In Lipids in Freshwater Ecosystems; Arts, M.T., Wainman, B.C., Eds.; Springer: New York, NY, USA, 1999; pp. 4-20.

100. Parrish, C.C. Lipids in Marine Ecosystems. ISRN Oceanogr. 2013, 1-16. [CrossRef]

101. Joseph, J.D. Distribution, and composition of lipids in marine invertebrates. Mar. Biog. Lipids Fats Oils 1989, 2, $49-144$.

102. Dembitsky, V.M.; Kashin, A.G.; Stefanov, K. Comparative investigation of phospholipids and fatty acids of freshwater molluscs from the Volga River basin. Comp. Biochem. Physiol. 1992, 102, 193-198. [CrossRef]

103. Dembitsky, V.M.; Rezanka, T.; Kashin, A.G. Comparative examination phospholipids and fatty acids from some Caspian invertebrates. Comp. Biochem. Physiol. 1993, 104, 617-622. [CrossRef]

104. Dembitsky, V.M.; Rezanka, T.; Kashin, A.G. Fatty acid and phospholipid compo $\neg$ sitions of freshwater molluscs Anadonta piscinalis and Limnaea fragilis from the river Volga. Comp. Biochem. Physiol. 1993, 105, 597-601.

105. Dembitsky, V.M.; Rezanka, T.; Kashin, A.G. Comparative study of the endemic freshwater fauna of Lake Baikal. 1. Phospholipid and fatty acid composition of two molluscs species Baicalia oviformis and Benedictia baicalensis. Comp. Biochem. Physiol. 1993, 106, 819-823. [CrossRef]

106. Dembitsky, V.M.; Rezanka, T.; Kashin, A.G. Comparative study of the endemic freshwater fauna of Lake Baikal. 4. Phospholipid and fatty acid composition two gastropod molluscs of genus Valvata. Comp. Biochem. Physiol. 1994, 107, 325-330. [CrossRef]

107. Brown, A.C.; Fraser, T.R. The connection of chemical constitution and physiological action. Trans. Roy. Soc. Edinburg 1868, 25, 224-242.

108. Cros, A.F.A. Action de l'Alcohol Amylique Sur l'Organisme. Ph.D. Thesis, University of Strasbourg, Strasbourg, France, 1863.

109. Richet, M.C. Note sur le rapport entre la toxicité et les propriétes physiques des corps. Compt. Rend. Soc. Biol. 1893, 45, 775-776.

110. Meyer, H. Zur Theorie der AIkoholnarkose. Arch. Exp. Path. Pharm. 1899, 42, 109-118. [CrossRef]

111. Overton, C.E. Studien über die Narkose; Fischer: Jena, Germany, 1901.

112. Hammett, L.P. Some relations between reaction rates and equilibrium constants. Chem. Rev. 1935, 17, 125-136. [CrossRef]

113. Hammett, L.P. The effect of structure upon the reactions of organic compounds. Benzene derivatives. J. Am. Chem. Soc. 1937, 59, 96-103. [CrossRef]

114. Taft, R.W. Separation of Polar, Steric and Resonance Effects in Reactivity. In Steric Effects in Organic Chemistry; Newman, M.S., Ed.; Wiley: Hoboken, NJ, USA, 1956; pp. 556-675.

115. Hansch, C.; Fujita, T. p- $\sigma-\pi$ Analysis. A method for the correlation of biological activity and chemical structure. J. Am. Chem. Soc. 1964, 86, 1616-1626. [CrossRef]

116. Hansch, C.; Leo, A. Exploring QSAR; American Chemical Society: Washington, DC, USA, 1995.

117. Sliwoski, G.; Kothiwale, S.; Meiler, J.; Lowe, E.W., Jr. Computational methods in drug discovery. Pharm. Rev. 2014, 66, 334-395. [CrossRef]

118. Leelananda, S.P.; Lindert, S. Computational methods in drug discovery. Beilstein J. Org. Chem. 2016, 12, 2694-2718. [CrossRef]

119. Kokh, D.B.; Amaral, M.; Bomke, J.; Grädler, U.; Musil, D. Estimation of drug-target residence times by $\tau$-random acceleration molecular dynamics simulations. J. Chem. Theor. Comput. 2018, 14, 3859-3869. [CrossRef] 
120. Cherkasov, A.M.; Muratov, E.N.; Fourches, D.; Varnek, A.; Baskin, I.I.; Cronin, M.; Dearden, J. QSAR modeling: Where have you been? Where are you going to? J. Med. Chem. 2014, 57, 4977-5010. [CrossRef]

121. Burov, Y.V.; Poroikov, V.V.; Korolchenko, L.V. National system for registration and biological testing of chemical compounds: Facilities for new drugs search. Bull. Natl. Center Biol. Act. Comp. 1990, 1, 4-25.

122. Muratov, E.N.; Bajorath, J.; Sheridan, R.P.; Tetko, I.; Filimonov, D.; Poroikov, V.; Oprea, T. QSAR without borders. Chem. Soc. Rev. 2020, 49, 3525-3564. [CrossRef] [PubMed]

123. Poroikov, V.V.; Filimonov, D.A.; Gloriozova, T.A.; Lagunin, A.A.; Druzhilovskiy, D.S.; Rudik, A.V. Computer-aided prediction of biological activity spectra for organic compounds: The possibilities and limitations. Russ. Chem. Bull. 2019, 68, $2143-2154$. [CrossRef]

124. Dembitsky, V.M.; Savidov, N.; Poroikov, V.V.; Gloriozova, T.A.; Imbs, A.B. Naturally occurring aromatic steroids and their biological activities. Appl. Microbiol. Biotechnol. 2018, 102, 4663-4674. [CrossRef]

125. Dembitsky, V.M.; Gloriozova, T.A.; Savidov, N. Steroid phosphate esters and phosphonosteroids and their biological activities. Appl. Microbiol. Biotechnol. 2018, 102, 7679-7692. [CrossRef]

126. PASS. Available online: http:/ / www.way2drug.com/passonline/ (accessed on 30 November 2021).

127. Savidov, N.; Gloriozova, T.A.; Poroikov, V.V.; Dembitsky, V.M. Highly oxygenated isoprenoid lipids derived from fungi and fungal endophytes: Origin and biological activities. Steroids 2018, 140, 114-124. [CrossRef]

128. Vil, V.; Terent'ev, A.O.; Al Quntar, A.A.A.; Gloriozova, T.A.; Savidov, N.; Dembitsky, V.M. Oxetane-containing metabolites: Origin structures, and biological activities. Appl. Microbiol. Biotechnol. 2019, 103, 2449-2467. [CrossRef]

129. Vil, V.A.; Gloriozova, T.A.; Terent'ev, A.O.; Savidov, N.; Dembitsky, V.M. Hydroperoxides derived from marine sources: Origin and biological activities. Appl. Microbiol. Biotechnol. 2019, 103, 1627-1642. [CrossRef]

130. Vil, V.A.; Gloriozova, T.A.; Poroikov, V.V.; Terent'ev, A.O.; Savidov, N.; Dembitsky, V.M. Naturally occurring of $\alpha, \beta$-diepoxycontaining compounds: Origin, structures, and biological activities. Appl. Microbiol. Biotechnol. 2019, 103, 3249-3264. [CrossRef]

131. Vil, V.A.; Terent'ev, A.O.; Savidov, N.; Gloriozova, T.A.; Poroikov, V.V.; Pounina, T.A.; Dembitsky, V.M. Hydroperoxy steroids and triterpenoids derived from plant and fungi: Origin, structures and biological activities. J. Steroid Biochem. Mol. Biol. 2019, 190, 76-87. [CrossRef]

132. Desbois, A.P.; Smith, V.J. Antibacterial free fatty acids: Activities, mechanisms of action and biotechnological potential. Appl. Microbiol. Biotechnol. 2010, 85, 1629-1642. [CrossRef]

133. Harada, H.; Yamashita, U.; Kurihara, H. Antitumor activity of palmitic acid found as a selective cytotoxic substance in a marine red alga. Anticancer Res. 2002, 22, 2587-2590.

134. Wongtangtintharn, S.; Oku, H.; Iwasaki, H.; Toda, T. Effect of branched-chain fatty acids on fatty acid biosynthesis of human breast cancer cells. J. Nutr. Sci. Vitaminol. 2004, 50, 137-143. [CrossRef]

135. Taormina, V.M.; Unger, A.L.; Schiksnis, M.R.; Torres-Gonzalez, M.; Kraft, J. Branched-chain fatty acids-An underexplored class of dairy-derived fatty acids. Nutrients 2020, 12, 2875. [CrossRef]

136. Ciuffreda, E.; Bevilacqua, A.; Sinigaglia, M.; Corbo, M.R. Alicyclobacillus spp.: New insights on ecology and preserving food quality through new approaches. Microorganisms 2015, 3, 625-640. [CrossRef]

137. Oshima, M.; Ariga, T. Omega-cyclohexyl fatty acids in acidophilic thermophilic bacteria. Studies on their presence, structure, and biosynthesis using precursors labeled with stable isotopes and radioisotopes. J. Biol. Chem. 1975, 250, 6963-6968. [CrossRef]

138. De Rosa, M.; Gambacorta, A.; Minale, L.; Bu'lock, J.D. The formation of $\omega$-cyclohexyl-fatty acids from shikimate in an acidophilic thermophilic bacillus. A new biosynthetic pathway. Biochem. J. 1972, 128, 751-754. [CrossRef] 